\title{
GENE PROFILING IDENTIFIES COMMONALITIES IN NEURONAL PATHWAYS IN EXCITOTOXICITY: EVIDENCE FAVOURING CELL CYCLE RE-ACTIVATION IN CONCERT WITH OXIDATIVE STRESS
}

Minghui Jessica Chen ${ }^{\mathbb{I I}}$, Jian Ming Jeremy $\mathrm{Ng}^{\mathbb{I I 1}}$, Zhao Feng Peng ${ }^{2,3}$, Jayapal Manikandan ${ }^{4}$, Yann Wan Yap ${ }^{6}$, Roxana M. Llanos ${ }^{6}$, Philip M. Beart*5 ${ }^{5}$ Nam Sang Cheung $*^{6}$

${ }^{1}$ Menzies Research Institute, University of Tasmania, Hobart, Tasmania 7000, Australia.

Department of ${ }^{2}$ Biochemistry, Yong Loo Lin School of Medicine, National University of Singapore, 8 Medical Drive, Singapore 117597.

${ }^{3}$ Key Laboratory of Biogeology and Environmental Geology of the Ministry of Education, University of Geosciences, Wuhan 430074, P.R. China

${ }^{4}$ Center of Excellence in Genomic Medicine Research (CEGMR), King Fahad Medical Research Center, King AbdulAziz University, Jeddah 21589, Saudi Arabia

${ }^{5}$ Florey Neuroscience Institutes and Department of Pharmacology, University of Melbourne, Victoria 3010, Australia

${ }^{6}$ Centre for Cellular and Molecular Biology, School of Life and Environmental Sciences, Deakin University, Burwood, Victoria 3125, Australia.

"II Minghui Jessica Chen and Jian Ming Jeremy Ng contributed equally to this study.

* Joint-corresponding authors and to whom proofs and reprint requests should be addressed: Dr Steve Nam Sang Cheung, School of Life and Environmental Sciences, Deakin University, Burwood, Victoria 3125, Australia. Tel: +61392446100, E-mail: steve.cheung@deakin.edu.au 
Running title: Commonalities in iGluRs global gene profiles

\begin{abstract}
:
Excitotoxicity, induced by the aberrant rise in cytosolic $\mathrm{Ca}^{2+}$ level, is a major neuropathological process in numerous neurodegenerative disorders. It is triggered when extracellular glutamate (Glu) concentration reaches neuropathological levels resulting in dysregulation and hyper-activation of ionotropic glutamate receptor subtype (iGluRs). Even though all three members of the iGluRs, namely N-methyl-D-aspartate (NMDAR), $\alpha$-amino-3-hydroxy-5-methyl-4-isoxazolepropionic acid (AMPAR) and kainate (KAR) receptors are implicated in excitotoxicity, their individual contributions to downstream signaling transduction have not been explored. In this study, we report a comprehensive description of the recruitment of cellular processes in neurons upon iGluR activation during excitotoxicity through temporal $(5 \mathrm{~h}, 15 \mathrm{~h}$ and $24 \mathrm{~h})$ global gene profiling of AMPA, KA, NMDA and Glu excitotoxic models. DNA microarray analyses of mouse primary cortical neurons treated with these four pharmacological agonists are further validated via real-time PCR. Bi-model analyses against Glu model demonstrate that NMDARs and KARs play a more pivotal role in Glumediated excitotoxicity, with a higher degree of global gene profiling overlaps, as compared to that of AMPARs. Comparison of global transcriptomic profiles reveals aberrant calcium ion binding and homeostasis, organellar (lysosomal and endoplasmic reticulum) stress, oxidative stress, cell cycle reentry and activation of cell death processes as the main pathways that are significantly modulated across all excitotoxicity models. Singular profile analyses demonstrate substantial transcriptional regulation of numerous cell cycle proteins. For the first time, we show that iGluR activation forms the basis of cell cycle re-activation, and together with oxidative stress fulfill the "two-hit" hypothesis that accelerates neurodegeneration.
\end{abstract}

(246 words) 


\section{Keywords}

- Excitotoxicity

- ionotropic

- Glutamate

- Ischemic stroke

- Cell cycle re-activation

- Neuronal death

- Microarray

Number of tables: 3

Number of figures: 5

Number of supplementary tables: 4

1. Contract Grant sponsor: NHMRC Project Grant APP1023646

2. PMB is a Research Fellow (APP1020401) of the NHMRC (Australia). 


\section{Introduction}

L-Glutamate (Glu) is the most abundant excitatory neurotransmitter in the central nervous system (CNS) and is the only physiological agonist activating for glutamate receptors (GluRs) in the mammalian brain. GluRs play important roles in structuring neurocognitive processes underlying memory and learning (Mukherjee and Manahan-Vaughan, 2012). Therefore, when the regulation of GluR activation is impaired, not only its signaling properties are affected, but the consequences can also lead to cell death via excitotoxicity. Excitotoxicity is a general term that defines a damageinflicting cellular process mediated via overstimulation of GluRs to effect a rise in cytosolic calcium ion level (Arundine and Tymianski, 2003). Because cellular indices reflecting excitotoxic damage are altered early in the pathogenesis of various neurodegenerative diseases such as Alzheimer's disease (AD; (Hynd et al., 2004)), dementia associated with Down syndrome (DS; (Scheuer et al., 1996)) and acute neurological deficits due to traumatic brain injury (TBI) and stroke (Arundine and Tymianski, 2004), excitotoxicity, is believed to be one of the primary upstream events that induces neuronal injury at a cellular level.

Depending on their individual mode of activation, GluR are grouped into either metabotropic (mGluRs) or ionotropic (iGluRs) GluRs (Niciu et al., 2012). While mGluRs indirectly activate ion channel via signaling pathways that involve $G$ proteins, iGluRs possess intrinsic ion channel activities. Therefore, during excitotoxicity, neuronal cell death is mediated by two concurrent yet distinct signaling processes determined by both iGluRs and mGluRs (Lea and Faden, 2003). In particular, iGluRs are made up of N-methyl-D-aspartate (NMDA), $\alpha$-amino-3-hydroxy-5-methyl-4isoxazolepropionic acid (AMPA) and kainate (KA) receptor subtypes which are named after their specific pharmacological agonists active at different intrinsic ligand-gated ion channel activity that 
allows passage of $\mathrm{Na}^{+}$and $\mathrm{Ca}^{2+}$ ions through a pore. All three subtypes of iGluRs (NMDAR, AMPAR and KAR) are actively involved during excitotoxic neuronal cell death. The NMDAR plays a major role due to its abundant expression and highest $\mathrm{Ca}^{2+}$ permeability (Hara and Snyder, 2007). Studies have shown that excessive NMDAR activation induces $\mathrm{Ca}^{2+}$ influx and release from intracellular stores, resulting in the activation of cytoplasmic proteases such as calcium-activated calpains (Simpkins et al., 2003) that hydrolyze cytoskeletal proteins. An example of such cytoskeletal protein is $\alpha$-fodrin (Posner et al., 1995; Siman et al., 1989). Furthermore, NMDAR activation can result in the destabilization of lysosomes and the release of lysosomal cathepsins, causing cell death (Graber et al., 2004; Tenneti et al., 1998). Likewise, dysregulation of AMPAR and KAR also induces excitotoxicity in neurons (Jayakar and Dikshit, 2004; Sattler and Tymianski, 2001; Vincent and Mulle, 2009). Indeed, we were the first to demonstrate that AMPA alone could produce apoptoticlike injury (Larm et al., 1997), just as can KA, with injury likely to exert an apoptotic-necrotic continuum of programmed cell death (Cheung et al., 1998).

To date, the consequences of activation of individual iGluRs subtypes in downstream signal transduction during excitotoxicity has not been comprehensively and simultaneously explored in a comparative platform, impeding an understanding of the relative contributions of individual iGluRs, be that via convergent or divergent cellular pathways, towards excitotoxic damage. In our current study, global transcriptomic profiling was employed to elucidate downstream signaling pathways, in terms of amplification and diversification, subsequent to different iGluR activation to model the sequence of events subsequent to extracellular Glu in the brain reaching pathological concentrations. Here, the DNA microarray technique was applied to four excitotoxic models induced by a) the general GluR agonist, Glu, b) AMPAR agonist, AMPA, c) NMDAR agonist, NMDA and d) KAR 
agonist, KA. Subsequent comparative global gene profile analysis was performed to elucidate the major primary biological processes regulated by iGluRs in the trigger of excitotoxicity during Glumediated neuronal injury. Our study is the first to attempt global gene profiling of this type and scale to elucidate the pathobiology of excitotoxicity. Briefly, oxidative stress and cell cycle re-activation were identified as the primary cellular pathways that were significantly modulated. The specific association of cell cycle-reactivation with iGluR activation provided interesting evidence for the occurrence of a 'two-hit' hypothesis in excitotoxicity that has been previously postulated by others for the basis of neurodegeneration in AD pathogenesis (Zhu et al., 2004, 2007). 


\section{Materials and methods}

\subsection{Murine Neocortical Neuronal Cultures}

Neocortical neurons (gestational days 15 or 16) obtained from foetal cortices of Swiss albino mice were used to prepare the primary cultures as previous described with minor modifications (Cheung et al., 2000). Dissected cortices were subjected to trypsin digestion and mechanical trituration. Cells were collected by centrifugation and resuspended in Neurobasal $^{\mathrm{TM}}$ (NB) medium containing $2.5 \%$ B27 supplement, 1\% penicillin, 1\% streptomycin, $0.25 \%$ GlutaMAX-1 supplement and 10\% dialyzed foetal calf serum. 24-Well plates previously coated with poly-D-lysine $(100 \mu \mathrm{g} / \mathrm{ml})$ were seeded with cells to a density of $2 \times 10^{5}$ cells $/ \mathrm{cm}^{2}$ and used for subsequent experiments. Cultures were maintained in a humidified $5 \% \mathrm{CO}_{2}$ and $95 \%$ air incubator at $37^{\circ} \mathrm{C}$. Immunocytochemical staining of the cultures at day 5 in vitro for microtubule-associated protein-2 and glial fibrillary acidic protein revealed > $95 \%$ of the cells were neurons with minimal contamination by glia (Cheung et al., 1998). All experiments involving animals were approved by the National University of Singapore, and were in accordance with the US Public Health Service guide for the care and use of laboratory animals.

\subsection{Drug Preparation and Treatment}

Glu, NMDA, KA and S-AMPA (Sigma-Aldrich) were freshly prepared prior to usage to achieve stock concentrations of 100mM. Working concentrations (Glu $250 \mu \mathrm{M}$, NMDA $200 \mu \mathrm{M}$, KA 100 $\mu \mathrm{M}$ and $S$-AMPA $300 \mu \mathrm{M}$ ) were achieved by dilution with NB medium. 


\subsection{Total RNA extraction and isolation}

RNA was extracted using RNeasy Mini Kit (Qiagen Cat. No. 74104) according to the manufacturer's instructions. All pipette tips used were RNase-free. Each sample was prepared from $1 \times 10^{6}$ cultured cells. RNA concentration was determined spectrophotometrically using Nanodrop ND-1000 Version 3.2.1 and RNA quality was determined using a E-gene HDA-GT12 genetic analyzer.

\subsection{Microarray analysis using Illumina Mouse Ref8 Ver.1.1 hybridization beadchips}

Microarray was carried out using Illumina ${ }^{\circledR}$ Mouse Ref8 Ver.1.1 arrays. For each GluR agonist treatment, the assignment of the arrays was as follow: $5 \mathrm{~h}(\mathrm{n}=3), 15 \mathrm{~h}(\mathrm{n}=3)$, and $24 \mathrm{~h}(\mathrm{n}=3)$ and control $(\mathrm{n}=6)$. Each RNA sample (500ng) was reverse transcribed using T7 Oligo(dT) primer to form first

strand cDNA containing a T7 promoter sequence, which was subsequently used for the second strand cDNA synthesis (employing DNA polymerase and Rnase $\mathrm{H}$ to simultaneously degrade the RNA and to synthesize second strand cDNA). The cDNAs were purified to remove RNA, primers, enzymes, and salts that would inhibit in vitro transcription. Finally in vitro transcription was employed to generate multiple copies of biotinylated cRNA from the double-stranded cDNA templates. All previously mentioned procedures were performed using Illumina ${ }^{\circledR}$ TotalPrep RNA Amplification Kit. cRNA yields were quantitated using the NanoDrop ND-1000.

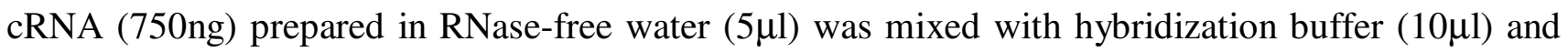
preheated to $65^{\circ} \mathrm{C}$ for $5 \mathrm{~min}$. Assay samples were then fully loaded onto the large sample port of each array on the beadchip. Beadchips were incubated in a humidified hybridization chamber at $58^{\circ} \mathrm{C}$ for 
17h. The following day, the IntelliHyb seal on the beadchip was removed to expose all the arrays. Beadchips were blocked and labeled with streptavidin-Cy3, followed by stringency buffer washes and dried. The hybridization process was carried out according to the manufacturer's instruction (Illumina Inc.). Beadchips were then ready for scanning on the Illumina ${ }^{\circledR}$ scanner using Bead Studio software at Scan Factor $=0.8$.

\subsection{Microarray data collection and analysis}

Initial analysis of the scanned images was performed using BeadScan (Illumina). The absolute data (signal intensity, detection call and detection P-value) were exported into GeneSpringGX 7.3 (Agilent Technologies, CA, USA) software for analysis by a parametric test based on crossgene error model (PCGEM). A one-way analysis of variance (ANOVA) approach was used to identify differentially expressed genes. Array data were globally normalized using GeneSpring software. Firstly, all measurements on each chip were divided by the $50^{\text {th }}$ percentile value (per chip normalization). Secondly, each gene was normalized to the baseline value of the control samples (per gene normalization) using median. Then genes were filtered on fold change \pm 1.5 fold against controls in at least one of three conditions for each respective treatment. Finally, one-way ANOVA $(\mathrm{p}<0.05)$ and Benjamini-Hochberg False Discovery Rate (FDR) Correction were used to seek differentially expressed genes. Genes which were differentially expressed are annotated according to Gene Ontology-Biological process provided by the online bioinformatics resources Database for Annotation, Visualization and Integrated Discovery (DAVID) 6.7 (http://david.abcc.ncifcrf.gov/) (Dennis et al., 2003; Huang et al., 2009). All microarray data reported here are described in accordance with MIAME guidelines, and has been deposited in the NCBIs Gene Expression 
Omnibus (GEO; http://www.ncbi.nlm.nih.gov/geo/) and are accessible through GEO Series accession number GSE16035, GSE22993, GSE22994 and GSE19936.

\subsection{Real-time polymerase chain reaction (PCR)}

Eight differentially expressed genes were selected for validation of the microarray results in replicate by quantitative real-time PCR in three independent experiments. The same total RNAs used for microarray from mouse culture treated with $250 \mu \mathrm{M}$ Glu were reverse transcribed to cDNAs according to steps specified by the manufacturer (Applied Biosystems Taqman reverse transcription reagents). The experiment set up, briefly, consisted of Taqman master mix $(20 \mu 1)$ and cDNA or water (NTC; both $5 \mu \mathrm{l}$ ) was added to the designated reaction well of a real-time PCR plate. The plate was then read using the 7000 Fast Real-Time PCR System with conditions according to the manufacturer's protocol. 


\section{Results}

Overall, cellular transcriptional regulation was assessed in excitotoxic models employing $250 \mu \mathrm{M}$ Glu, $200 \mu \mathrm{M}$ NMDA, $300 \mu \mathrm{M}$ AMPA and $100 \mu \mathrm{M}$ KA over a 24-hour period using Illumina ${ }^{\circledR}$ Mouse Ref8 V1.1 genechips. The raw transcriptional signal data from individual arrays were then subjected to statistical filtering using one-way ANOVA, p <0.05 and Benjamini-Hochberg FDR. Gene probes were considered to be significantly regulated when they demonstrated gene expression changes of at least \pm 1.5 folds in a minimum of one out of the three time-points (5h, $15 \mathrm{~h}$ and $24 \mathrm{~h})$. All gene probes that passed these selection criteria were gathered to form the global transcriptomic data for each excitotoxic model. Transcriptomic profiles generated from the treatment of neurons with Glu (1,842 gene probes), NMDA (2,309 gene probes), AMPA (1,563 gene probes) and KA (3,800 gene probes) were organized side-by-side and partitioned to different fold-change categories (Figure 1). A substantial number of gene probes demonstrated greater than \pm 1.5 fold-changes in gene expression over the 24-hour period, with KA treatment generating the largest transcriptomic profile.

\subsection{Bi-model analyses of individual iGluRs profiles against that of Glu revealed the following decrease ordering of iGluRs activation dependence NMDARs $>$ KARs $>$ AMPARs during excitotoxicity}

Bi-model global transcriptomic profile comparisons using Glu model as the basis of analysis demonstrated that in rank order of highest to lowest degree of overlap, i.e. commonly occurring and differentially regulated gene probes, NMDA > KA > AMPA (Figure 2). NMDA (Figure 2A) and KA (Figure 2C) profiles were comparable, but they exhibited nearly double the number of Glu commonly 
occurring genes when compared to AMPA profile (Figure 2B). These profiles signify a greater reliance upon NMDAR and KAR-mediated signaling pathways to induce excitotoxicity during Glumediated neurotoxicity. A more in-depth analysis of the consistency in transcriptional regulatory trend demonstrated that the majority of the genes were similarly regulated at $15 \mathrm{~h}$ and $24 \mathrm{~h}$ respectively in all three iGluRs models (Figure 3).

\subsection{Simultaneous comparison of all four excitotoxic models identified several major common biological processes}

A concerted transcriptomic analysis of all four profiles revealed a total list of 583 common genes. Similarly, a detailed exploration of the transcriptional trend of these genes revealed a high degree of consistency at each respective time-point, which faltered upon inter-time-point examination across all three time-points (Figure 4), indicating a common temporal activation and/or inhibition of signaling pathways across all four excitotoxicity models, but with distinct progression outcome of each signaling cascade, i.e. either pursuant and persistent maintenance of initial activated/inhibitory state or directional change of pathway regulation.

Functional classification of these 583 RefSeq transcripts, which corresponded to 485 biologicallyannotated genes, identified several important and over-represented biological pathways relevant to the progression of excitotoxicity (Table 1). These include calcium homeostasis and binding, antioxidant response, cell death and cell survival processes. Notably, an overwhelming number of molecules involved in the promotion of mitotic cell cycle progression were transcriptionally elevated in all four models of excitotoxicity. Consistently, all members of these over-represented biological 
processes were significantly modulated at the expression level between the $5 \mathrm{~h}$ and $15 \mathrm{~h}$ time-points, implying the reported pathways constitute the early upstream cellular events in excitotoxicity.

I. Calcium ion homeostasis and binding: In all four excitotoxic models, genes encoding for $\mathrm{Ca}^{2+}$-dependent proteins and receptors (Gpr12, Prkcb and Rxfp3) were significantly downregulated, indicating the occurrence of aberrant calcium ion homeostasis. On the contrary, genes encoding for $\mathrm{Ca}^{2+}$-binding proteins (S100a6 and Anx (A2, A3 and A5) showed increased gene expression, providing further evidence of elevation of cytosolic $\mathrm{Ca}^{2+}$ level during excitotoxicity due to activation of iGluRs which triggers intrinsic $\mathrm{Ca}^{2+}$ channel activity.

II. Lysosomal stress: Aberrant elevation of cytosolic $\mathrm{Ca}^{2+}$ ion level and overproduction of reactive oxygen species (ROS) imposes organellar stress through disruption of the delicate balance of cellular ionic gradients and unregulated modifications of cellular proteins resulting in detrimental loss/gain-of function, all contributing to disturbance of normal cellular signaling. Analysis of the gene profiles of genes common to all four excitotoxic models revealed significant transcriptional activation of lysosomal resident proteins, indicative of some form of disorientation and/or stress imposed on the normal functioning of the lysosomes.

\section{Anti-oxidant responses}

Heat shock proteins (Hsps) and molecular chaperones: Organellar (ER and lysosomal) stress is especially prominent in excitotoxicity and evokes a cellular counteractive response to minimize electrophilic and oxidative burdens. Interestingly, comparative microarray analysis 
demonstrated that in our specific iGluR excitotoxic models, up-regulation of the majority of genes encoding for heat shock proteins (HSPs) and molecular chaperones (Hmox1, Srxn1, Hspa2, and Hspb8) and metal chaperones (Mt3) occurred at the 5h time-point, much earlier than that of Glu at $15 \mathrm{~h}$.

Glutathione (GSH) metabolism: Genes transcribing for members of the GSH anti-oxidative pathway were significantly up-regulated in all four models. However, AMPA and Glu models demonstrated significant elevation of GSH pathway genes at 15h, while NMDARs and KARs demonstrated earlier transcriptional response at $5 \mathrm{~h}$.

IV. Cell death: Majority of the genes encoding for proteins directly/indirectly involved in promotion of cell death (Angpt14, Casp6 and Ctnna1) were transcriptionally up-regulated. In addition, cell death was further accelerated by the down-regulation of anti-cell death protein (Bcl11b).

V. Cell homeostasis, survival and proliferation: In all four excitotoxic models, genes encoding for pro-survival/mitogenic proteins (Spp1 and Birc5 (also known as Survivin)) and growth factors (Igf2 and Igfbp5) were up-regulated between the $5 \mathrm{~h}$ and $15 \mathrm{~h}$ time-points. These responses indicate a cellular response to suppress cell death mechanisms.

VI. Mitotic cell cycle: Numerous genes encoding for cell cycle proteins that promote cell cycle re-entry were up-regulated in all four excitotoxic models between $5 \mathrm{~h}$ and $15 \mathrm{~h}$. This observation is totally unprecedented in the context of excitotoxicity. Under physiological 
conditions, neurons are in the post-mitotic and differentiated state. Aberrant cell cycle reentry has been implicated in the pathogenesis of several neurological conditions such as $\mathrm{AD}$, DS, Huntington's disease, Pick's disease and stroke (Camins et al., 2008; Pelegri et al., 2008). Recent studies on $\mathrm{AD}$ suggested this cellular event to be a part of the neuronal death process (Lopes et al., 2009a, 2009b). p53, the main keeper of genome integrity, was significantly down-regulated (denoted as Trp53 in the table), indicating a failure in the cell cycle checkpoint system that enhances re-activation of cell cycle process.

\subsection{Singular profile analysis highlights cell cycle re-activation as a prominent biological process during excitotoxicity}

The majority of proteins involved in mitotic cell cycle process showed significant transcriptional modulation across all four profiles (Table 2). Gene expression of proteins promoting positive regulation of mitosis occurred between $5 \mathrm{~h}$ and $15 \mathrm{~h}$ post-treatment, providing strong evidence for the early occurrence of cell cycle re-entry upon iGluRs induction. Detailed temporal fold-expression of individual genes can be found in Supplementary Tables 1-4.

\subsection{Validation of Glu global transcriptomic profiles via real-time PCR}

Microarray data were validated via real-time PCR using the same total RNA samples previously employed for microarray analysis. Similar temporal transcriptional regulatory trends were observed for the genes listed in Table 3. 


\section{Discussion}

Excitotoxicity is well accepted to be a cell death process contributing to both acute and chronic neurodegenerative conditions (Doble, 1999). Although rises in intracellular $\mathrm{Ca}^{2+}$ subsequent to activation of NMDARs play a central role in most discussions of excitotoxicity, the recruitment of cell signaling cascades is likely to be more complex. Here, we sought to determine the individual contributions of over-stimulated iGluRs to the excitotoxic process by transcriptomic profiling. Simultaneous comparison of the global transcriptomic profiles of AMPA-, KA-, NMDA- and Glumediated excitotoxic injury revealed a higher degree of correlation in terms of number of similarlyregulated genes for KA and NMDA, rather than AMPA profiles, versus that of Glu as background. The differences might be due to: a) higher NMDAR and KAR expression on cell surfaces; b) AMPARs are depolarized before NMDARs; c) some AMPARs are $\mathrm{Ca}^{2+}$-impermeable. In the case of Glu, delay in cellular process activation may be accounted by dilution of the effective concentration of the agonist to activate iGluRs, due to concurrent sequestration of Glu molecules by mGluRs and Glu transporters. Key findings obtained by comparison of global transcriptomic profiles were that the main pathways modulated across all excitotoxic models were calcium ion binding and homeostasis, organellar stress, oxidative stress, cell cycle re-activation and activation of cell death processes. Notably, we show for the first time that iGluR activation forms the basis of cell cycle re-activation, and that with oxidative stress they together fulfill the "two-hit" hypothesis originally formulated for AD pathogenesis (Zhu et al., 2001, 2004, 2007), suggesting that oxidative stress and cell cycle dysregulation contribute hand-in-hand to neuronal loss during neurodegeneration (Figure 5). 
Aberrant expression of neuronal cell cycle proteins with resultant neuronal loss has been observed in post-mortem tissue from patients with neurodegenerative diseases such as AD, PD, ALS, DS and progressive supranuclear palsy (Nunomura et al., 2007; Woods et al., 2007) and acute neurological disorder such as stroke and TBI (Byrnes and Faden, 2007; Timsit and Menn, 2007). Accumulating evidence has demonstrated aberrant expression of cell-cycle-related molecules in the neurons of the hippocampus, subiculum, locus coeruleus and dorsal raphe nuclei. Cell cycle re-activation association to excitotoxicity has previously been reported on numerous occasions in models of excitotoxicity and stroke, amidst models of other neurodegenerative diseases such as the MPTP model of PD and superoxide dismutase-1 mouse model of ALS (Hoglinger et al., 2007; Nguyen et al., 2003; Verdaguer et al., 2003, 2004a), indicating a similar neuropathological incidence between these two cellular events which may not be a coincidence. Based on our findings, iGluRs activation may be the origin or an important part of the cause of mitotic dysfunction.

From profiling the genes involved in mitotic cell division for individual excitotoxicity (Table 2), it is apparent that numerous cell cycle-promoting proteins were transcriptionally up-regulated from $5 \mathrm{~h}$ and $15 \mathrm{~h}$. This finding is in agreement with an increase in gene expression of pro-mitogenic signals from growth factors. Interestingly, transcriptional up-regulation of cyclin D1 and D2 was observed in AMPA and KA models, but not in the NMDA and Glu models. This difference in temporal modulation of cyclin D could be explained by the earlier occurrence of cell cycle re-activation before the selected 5h time-points in NMDA and Glu profile as a result of the highest physiological abundance and calcium ion permeability of NMDARs out of the three iGluRs subtypes, which leads to the failure to capture the timeframe of cyclin D transcriptional modulation. As such, NMDA profiling demonstrated basal fold-change $(\sim 1.0)$ at $5 \mathrm{~h}$, followed by significant pursuing down- 
regulation at $15 \mathrm{~h}$ and $24 \mathrm{~h}$. On the other hand, L-cyclin D (Ccnd) transcriptional regulation was not present in the Glu profile, indicating an overall close to basal (between -1.50 to 1.50 fold) expression due to a neutralizing effect from the up and down-regulation of Cend in AMPA/KA and NMDA profiles respectively upon all iGluRs activation.

While activation of iGluRs during excitotoxicity may be the trigger for the initiation of cell cycle reactivation, oxidative stress may further facilitate and promote its progression (Bonda et al., 2010). Indeed, significant oxidative load, represented by the substantial transcriptional activation of Hsps, molecular chaperones and GSH pathway associated genes, was observed across all four excitotoxicity models. Oxidative stress in particular has been strongly linked to excitotoxic neuronal cell death in both multiple sclerosis and brain ischemia (Gonsette, 2008; Warner et al., 2004). Intriguingly, our study highlights that a "two-hit" hypothesis, originally put forward for neurodegeneration in $\mathrm{AD}$, involves both oxidative stress and aberrant cell cycle activation may apply to neuronal excitotoxicity (Zhu et al., 2001, 2007). In the current study, apart from oxidative stress, the two conditions paramount for aberrant cell cycle re-entry occur in neurons, namely (a) an elevation in cell cycle proteins and (b) an increase in pro-mitogenic signals, have been fulfilled. Even though mature neurons may express some cell cycle proteins, the amount produced is not sufficient to produce a substantial pro-mitogenic signal to drive the mature neuron to re-enter the cell cycle. Furthermore, some cell cycle proteins demonstrate diverse post-mitotic multi-functions that span various developmental stages of a neuron, including neuronal migration, axonal elongation, axonal pruning, dendrite morphogenesis and synaptic maturation, and plasticity (Frank and Tsai, 2009; Kim et al., 2009). As such, neuronal cell death requires the additional stimulus of pro-mitogenic molecules, such as thrombin, $A \beta$, ROS, nitric oxide and elevations in the level of such molecules will 
then trigger the mitogenic signaling cascades in injured neurons. Once mitogenic signaling is stimulated beyond a certain threshold, neurons appear to exit their quiescent state and re-enter the cell cycle and this "vulnerable" state eventually leads to their demise (Bonda et al., 2010).

To date, preclinical experiments employing inhibitors (flavopiridol, olomoucine or roscovitine) of cell cycle protein kinase family, CDKs, demonstrate improved behavioral outcomes and increased neuronal survival in a series of CNS disease models such as AD (Copani et al., 2001; Jorda et al., 2003; Verdaguer et al., 2004b), PD (Kruman and Schwartz, 2006), stroke (Osuga et al., 2000; Wang et al., 2002) and TBI (Hilton et al., 2008). All of these neuropathologies are believed to involve iGluR-mediated excitotoxicity and there is a literature suggesting inhibitors of CDKs are neuroprotective against excitotoxicity (Giardinia and Beart, 2002). Overall, our gene profiling indicate that oxidative stress and cell cycle re-entry are primary events taking place during iGluR overactivation in neurons and further support the "two-hit" hypothesis for excitotoxic neuronal cell death. More importantly, our study suggests that a combined therapeutic approach using drugs that salvage oxidative stress and prevent the onset of cell cycle may potentially delay death and provide neurons with "bonus" time for recovery during excitotoxicity associated with multiple neurodegenerative diseases.

\section{Acknowledgement}

This work is supported by: NSC and PMB, project grant funding from the National Health and Medical Research Council of Australia. PMB is a Research Fellow of the NHMRC (Australia). 


\section{References}

Arundine, M., Tymianski, M., 2003. Molecular mechanisms of calcium-dependent neurodegeneration in excitotoxicity. Cell Calcium 34, 325-337.

Arundine, M., Tymianski, M., 2004. Molecular mechanisms of glutamate-dependent neurodegeneration in ischemia and traumatic brain injury. Cell Mol Life Sci 61, 657-668.

Bonda, D.J., Bajic, V.P., Spremo-Potparevic, B., Casadesus, G., Zhu, X., Smith, M.A., Lee, H.G., 2010. Review: cell cycle aberrations and neurodegeneration. Neuropathol Appl Neurobiol 36, 157-163.

Byrnes, K.R., Faden, A.I., 2007. Role of cell cycle proteins in CNS injury. Neurochem Res 32, 17991807.

Camins, A., Pallas, M., Silvestre, J.S., 2008. Apoptotic mechanisms involved in neurodegenerative diseases: experimental and therapeutic approaches. Methods Find Exp Clin Pharmacol 30, 4365 .

Cheung, N.S., Carroll, F.Y., Larm, J.A., Beart, P.M., Giardina, S.F., 1998. Kainate-induced apoptosis correlates with c-Jun activation in cultured cerebellar granule cells. J Neurosci Res 52, 69-82.

Cheung, N.S., Beart, P.M., Pascoe, C.J., John, C.A., Bernard, O., 2000. Human Bcl-2 protects against AMPA receptor-mediated apoptosis. J Neurochem 74, 1613-1620.

Copani, A., Uberti, D., Sortino, M.A., Bruno, V., Nicoletti, F., Memo, M., 2001. Activation of cellcycle-associated proteins in neuronal death: a mandatory or dispensable path? Trends Neurosci $24,25-31$. 
Dennis, G., Jr., Sherman, B.T., Hosack, D.A., Yang, J., Gao, W., Lane, H.C. Lempicki, R.A., 2003. DAVID: Database for annotation, visualization, and integrated discovery. Genome Biol 4, P3.

Ding, S., Fellin, T., Zhu, Y., Lee, S.Y., Auberson, Y.P., Meaney, D.F., Coulter, D.A., Carmignoto, G., Haydon, P.G., 2007. Enhanced astrocytic Ca2+ signals contribute to neuronal excitotoxicity after status epilepticus. J Neurosci 27, 10674-10684.

Doble, A., 1999. The role of excitotoxicity in neurodegenerative disease: implications for therapy. Pharmacol Ther 81, 163-221.

Frank, C.L., Tsai, L.H., 2009. Alternative functions of core cell cycle regulators in neuronal migration, neuronal maturation, and synaptic plasticity. Neuron 62, 312-326.

Giardina, S.F., Beart, P.M., 2002. Kainate receptor-mediated apoptosis in primary cultures of cerebellar granule cells is attenuated by mitogen-activated protein and cyclin-dependent kinase inhibitors. Br J Pharmacol 135, 1733-1742.

Gonsette, R.E., 2008. Oxidative stress and excitotoxicity: a therapeutic issue in multiple sclerosis? Mult Scler 14, 22-34.

Graber, S., Maiti, S., Halpain, S., 2004. Cathepsin B-like proteolysis and MARCKS degradation in sublethal NMDA-induced collapse of dendritic spines. Neuropharmacol 47, 706-713.

Hara, M.R., Snyder, S.H., 2007. Cell signaling and neuronal death. Annu Rev Pharmacol Toxicol 47, $117-141$.

Hilton, G.D., Stoica, B.A., Byrnes, K.R., Faden, A.I., 2008. Roscovitine reduces neuronal loss, glial activation, and neurologic deficits after brain trauma. J Cereb Blood Flow Metab 28, 18451859. 
Hoglinger, G.U., Breunig, J.J., Depboylu, C., Rouaux, C., Michel, P.P., Alvarez-Fischer, D., Boutillier, A.L., Degregori, J., Oertel, W.H., Rakic, P., Hirsch, E.C., Hunot, S., 2007. The $\mathrm{pRb} / \mathrm{E} 2 \mathrm{~F}$ cell-cycle pathway mediates cell death in Parkinson's disease. Proc Natl Acad Sci U S A $104,3585-3590$.

Huang, D.W., Sherman, B.T., Lempicki, R.A., 2009. Systematic and integrative analysis of large gene lists using DAVID Bioinformatics Resources. Nature Protoc 4, 44-57.

Hynd, M.R., Scott, H.L., Dodd, P.R., 2004. Differential expression of N-methyl-D-aspartate receptor NR2 isoforms in Alzheimer's disease. J Neurochem 90, 913-919.

Jayakar, S.S., Dikshit, M., 2004. AMPA receptor regulation mechanisms: future target for safer neuroprotective drugs. Int J Neurosci 114, 695-734.

Jorda, E.G., Verdaguer, E., Canudas, A.M., Jimenez, A., Bruna, A., Caelles, C., Bravo, R., Escubedo, E., Pubill, D., Camarasa, J., Pallas, M., Camins, A., 2003. Neuroprotective action of flavopiridol, a cyclin-dependent kinase inhibitor, in colchicine-induced apoptosis. Neuropharmacology 45, 672-683.

Kim, A.H., Puram, S.V., Bilimoria, P.M., Ikeuchi, Y., Keough, S., Wong, M., Rowitch, D., Bonni, A., 2009. A centrosomal Cdc20-APC pathway controls dendrite morphogenesis in postmitotic neurons. Cell 136, 322-336.

Kruman, I., Schwartz, E., 2006. Methods of neuroprotection by cyclin-dependent kinase inhibition. US 20080182853.

Larm, J.A., Cheung, N.S., Beart, P.M., 1997. Apoptosis induced via AMPA-selective glutamate receptors in cultured murine cortical neurons. J Neurochem 69, 617-622.

Lea, P.M. $4^{\text {th }}$, Faden, A.I., 2003. Modulation of metabotropic glutamate receptors as potential treatment for acute and chronic neurodegenerative disorders. Drug News Perspect 16, 513-522. 
Lopes, J.P., Blurton-Jones, M., Yamasaki, T.R., Agostinho, P., LaFerla, F.M., 2009a. Activation of cell cycle proteins in transgenic mice in response to neuronal loss but not amyloid-beta and tau pathology. J Alzheimers Dis 16, 541-549.

Lopes, J.P., Oliveira, C.R., Agostinho, P., 2009b. Cell cycle re-entry in Alzheimer's disease: a major neuropathological characteristic? Curr Alzheimer Res 6, 205-212.

Mukherjee, S., Manahan-Vaughan, D., 2012. Role of metabotropic glutamate receptors in persistent forms of hippocampal plasticity and learning. Neuropharmacology. [Epub ahead of print]

Nguyen, M.D., Boudreau, M., Kriz, J., Couillard-Despres, S., Kaplan, D.R., Julien, J.P., 2003. Cell cycle regulators in the neuronal death pathway of amyotrophic lateral sclerosis caused by mutant superoxide dismutase 1. J Neurosci 23, 2131-2140.

Niciu, M.J., Kelmendi, B., Sanacora, G., 2012. Overview of glutamatergic neurotransmission in the nervous system. Pharmacol Biochem Behav 100, 656-664.

Nunomura, A., Moreira, P.I., Lee, H.G., Zhu, X., Castellani, R.J., Smith, M.A., Perry, G., 2007. Neuronal death and survival under oxidative stress in Alzheimer and Parkinson diseases. CNS Neurol Disord Drug Targets 6, 411-423.

Osuga, H., Osuga, S., Wang, F., Fetni, R., Hogan, M.J., Slack, R.S., Hakim, A.M., Ikeda, J.E., Park, D.S., 2000. Cyclin-dependent kinases as a therapeutic target for stroke. Proc Natl Acad Sci USA 97, 10254-10259.

Pelegri, C., Duran-Vilaregut, J., del Valle, J., Crespo-Biel, N., Ferrer, I., Pallas, M., Camins, A., Vilaplana, J., 2008. Cell cycle activation in striatal neurons from Huntington's disease patients and rats treated with 3-nitropropionic acid. Int J Dev Neurosci 26, 665-671. 
Posner, A., Raser, K.J., Hajimohammadreza, I., Yuen, P.W., Wang, K.K., 1995. Aurintricarboxylic acid is an inhibitor of mu- and m-calpain. Biochem Mol Biol Int 36, 291-299.

Sattler, R., Tymianski, M., 2001. Molecular mechanisms of glutamate receptor-mediated excitotoxic neuronal cell death. Mol Neurobiol 24, 107-129.

Scheuer, K., Maras, A., Gattaz, W.F., Cairns, N., Forstl, H., Muller, W.E., 1996. Cortical NMDA receptor properties and membrane fluidity are altered in Alzheimer's disease. Dementia 7, 210214.

Siman, R., Noszek, J.C., Kegerise, C., 1989. Calpain I activation is specifically related to excitatory amino acid induction of hippocampal damage. J Neurosci 9, 1579-1590.

Simpkins, K.L., Guttmann, R.P., Dong, Y., Chen, Z., Sokol, S., Neumar, R.W., Lynch, D.R., 2003. Selective activation induced cleavage of the NR2B subunit by calpain. J Neurosci 23, 1132211331.

Tenneti, L., D'Emilia, D.M., Troy, C.M., Lipton, S.A., 1998. Role of caspases in N-methyl-Daspartate-induced apoptosis in cerebrocortical neurons. J Neurochem 71, 946-959.

Timsit, S., Menn, B., 2007. Cerebral ischemia, cell cycle elements and Cdk5. Biotechnol J 2, 958966.

Verdaguer, E., Jimenez, A., Canudas, A.M., Jorda, E.G., Sureda, F.X., Pallas, M., Camins, A., $2004 a$. Inhibition of cell cycle pathway by flavopiridol promotes survival of cerebellar granule cells after an excitotoxic treatment. J Pharmacol Exp Ther 308, 609-616.

Verdaguer, E., Jorda, E.G., Canudas, A.M., Jimenez, A., Pubill, D., Escubedo, E., Camarasa, J., Pallas, M., Camins, A., 2004b. Antiapoptotic effects of roscovitine in cerebellar granule cells deprived of serum and potassium: a cell cycle-related mechanism. Neurochem Int 44, 251-261. 
Verdaguer, E., Jorda, E.G., Canudas, A.M., Jimenez, A., Sureda, F.X., Rimbau, V., Pubill, D., Escubedo, E., Camarasa, J., Pallas, M., Camins, A., 2003. 3-Amino thioacridone, a selective cyclin-dependent kinase 4 inhibitor, attenuates kainic acid-induced apoptosis in neurons. Neuroscience 120, 599-603.

Vincent, P., Mulle, C., 2009. Kainate receptors in epilepsy and excitotoxicity. Neuroscience 158, 309-323.

Wang, F., Corbett, D., Osuga, H., Osuga, S., Ikeda, J.E., Slack, R.S., Hogan, M.J., Hakim, A.M., Park, D.S., 2002. Inhibition of cyclin-dependent kinases improves CA1 neuronal survival and behavioral performance after global ischemia in the rat. J Cereb Blood Flow Metab 22, 171182.

Warner, D.S., Sheng, H., Batinic-Haberle, I., 2004. Oxidants, antioxidants and the ischemic brain. J Exp Biol 207, 3221-3231.

Woods, J., Snape, M., Smith, M.A., 2007. The cell cycle hypothesis of Alzheimer's disease: suggestions for drug development. Biochim Biophys Acta 1772, 503-508.

Zhu, X., Castellani, R.J., Takeda, A., Nunomura, A., Atwood, C.S., Perry, G., Smith, M.A., 2001. Differential activation of neuronal ERK, JNK/SAPK and p38 in Alzheimer disease: the 'two hit' hypothesis. Mech Ageing Dev 123, 39-46.

Zhu, X., Lee, H.G., Perry, G., Smith, M.A., 2007. Alzheimer disease, the two-hit hypothesis: an update. Biochim Biophys Acta 1772, 494-502.

Zhu, X., Raina, A.K., Perry, G., Smith, M.A., 2004. Alzheimer's disease: the two-hit hypothesis. Lancet Neurol 3, 219-226. 


\section{Conflict of interest}

The authors declare that they have no conflict of interest. 


\section{Figure Legends}

Figure 1. Classification of individual iGluRs global transcriptomic profiles (passed microarray selection criteria: total numbers of genes showing expression at least \pm 1.5 fold change in a minimum of one out of the three time-points (5h, 15h and 24h) and statistical examination using one-way ANOVA, $p<0.05$ and Benjamini-Hochberg FDR) according to specific time-points and fold-change expression up/down-regulated.

Figure 2. Bi-model global transcriptomic profile analysis of individual iGluRs agonists against Glu excitotoxic model. Venn diagrams demonstrating the number of gene probes common and mutually exclusive to both models [A] Glu against NMDA [B] Glu against AMPA and [C] Glu against KA.

Figure 3. Consistency in the transcriptional regulatory trend of the commonly occurring and significantly modulated gene probes in individual iGluRs against Glu excitotoxic models.

Figure 4. Overall consistency in the transcriptional regulatory trend of the commonly occurring and significantly modulated gene probes [A] at respective time-points (5h, 15h and 24h) and [B] across all three time points in all four excitotoxic models.

Figure 5. A schematic diagram summarizing the proposed mechanism after over-activation of iGluR. The significant increasing of cytosolic calcium after chronic stimulation of iGluR leads to aberrant calcium homeostasis and binding. In response, ER, mitochondria and lysosome act as calcium store by uptaking the cytosolic calcium, which lead to organelle stress and subsequent oxidative stress. At the same time, both calcium influx and oxidative stress trigger cell cycle re-activation in post-mitotic neurons. Mechanistically oxidative stress and cell cycle re-entry work 'hand-in-hand' to mediate programmed cell death in excitotoxic models. 


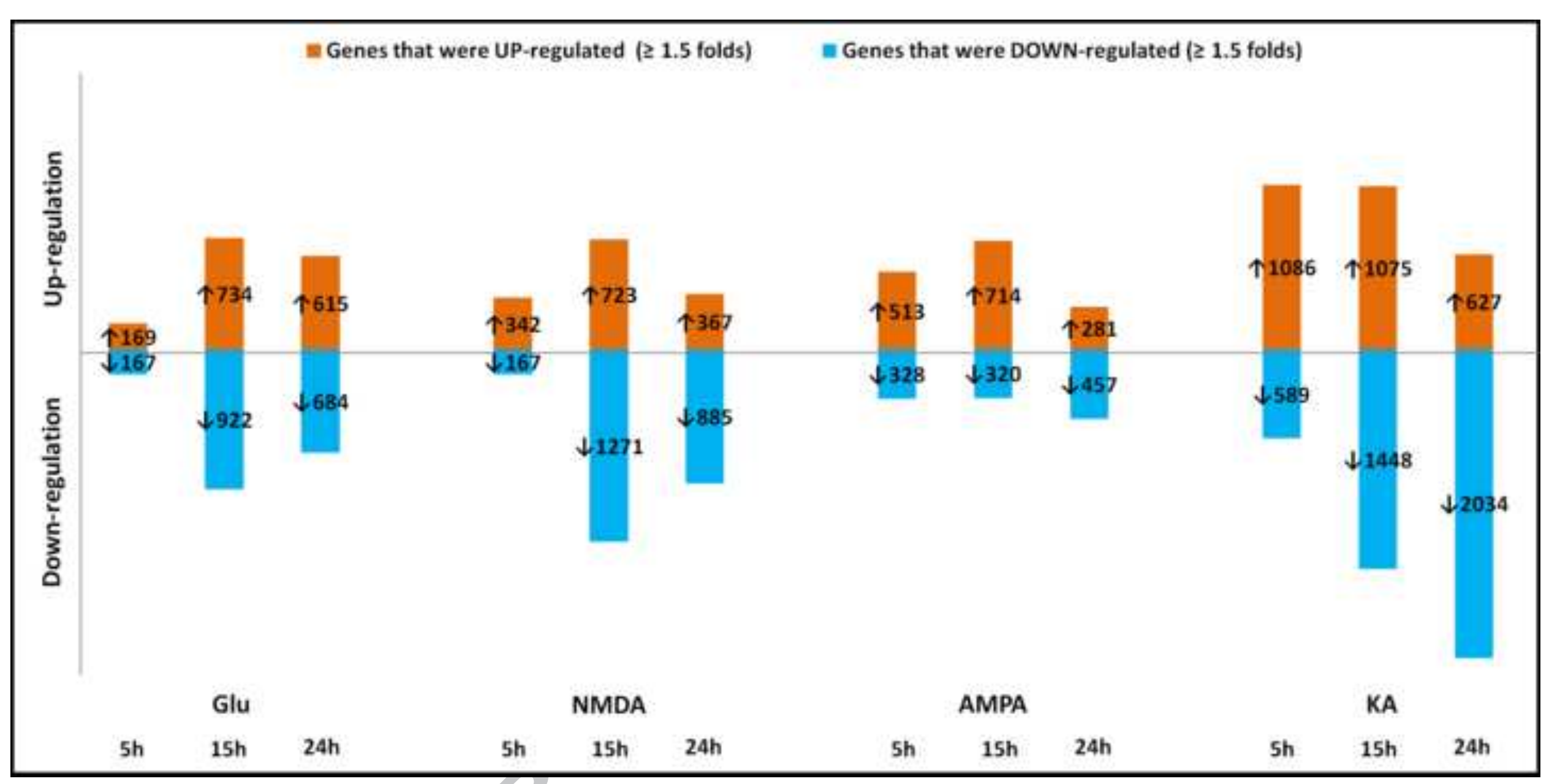




\section{ACCEPTED MANUSCRIPT}

A

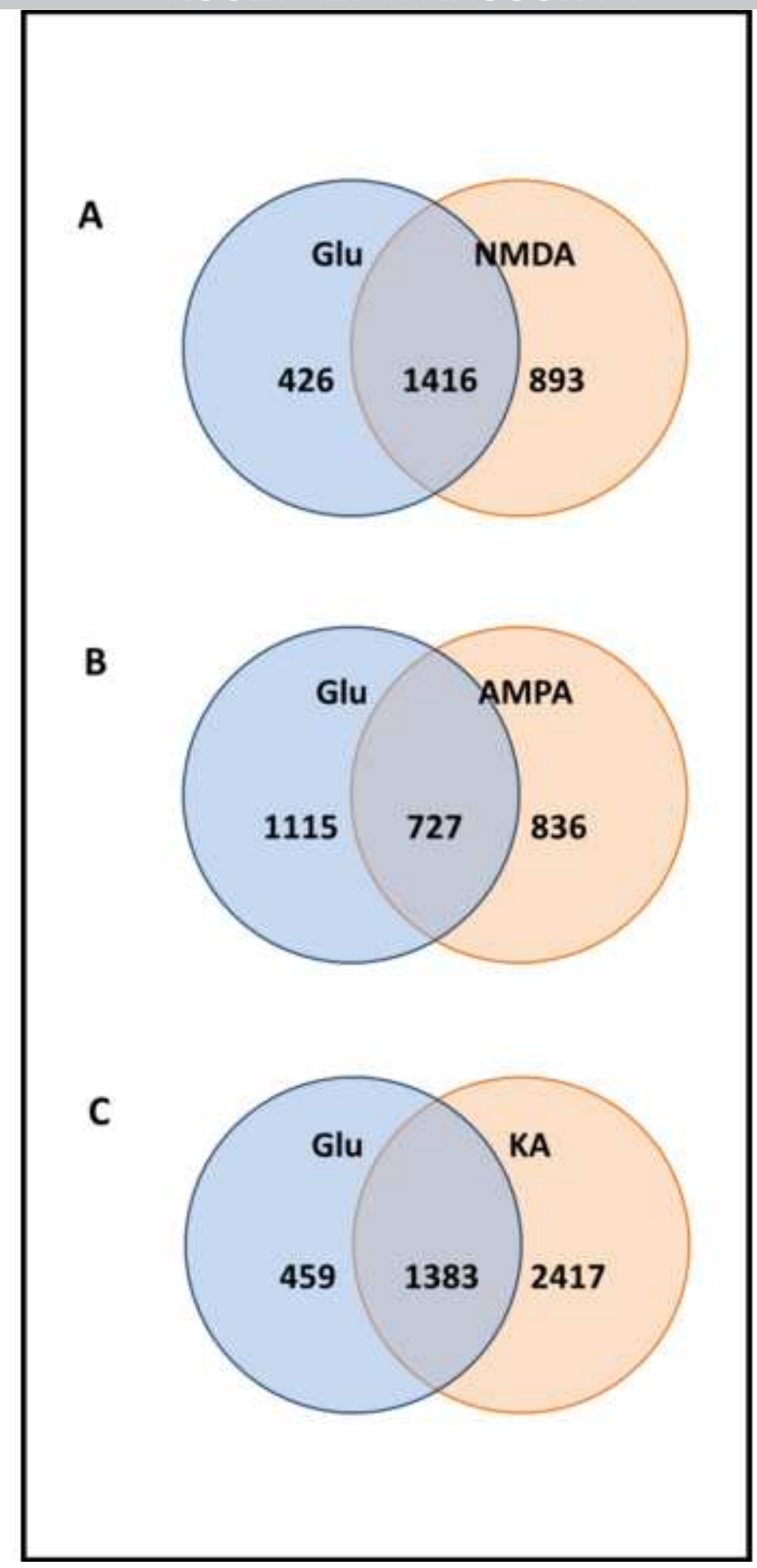

B

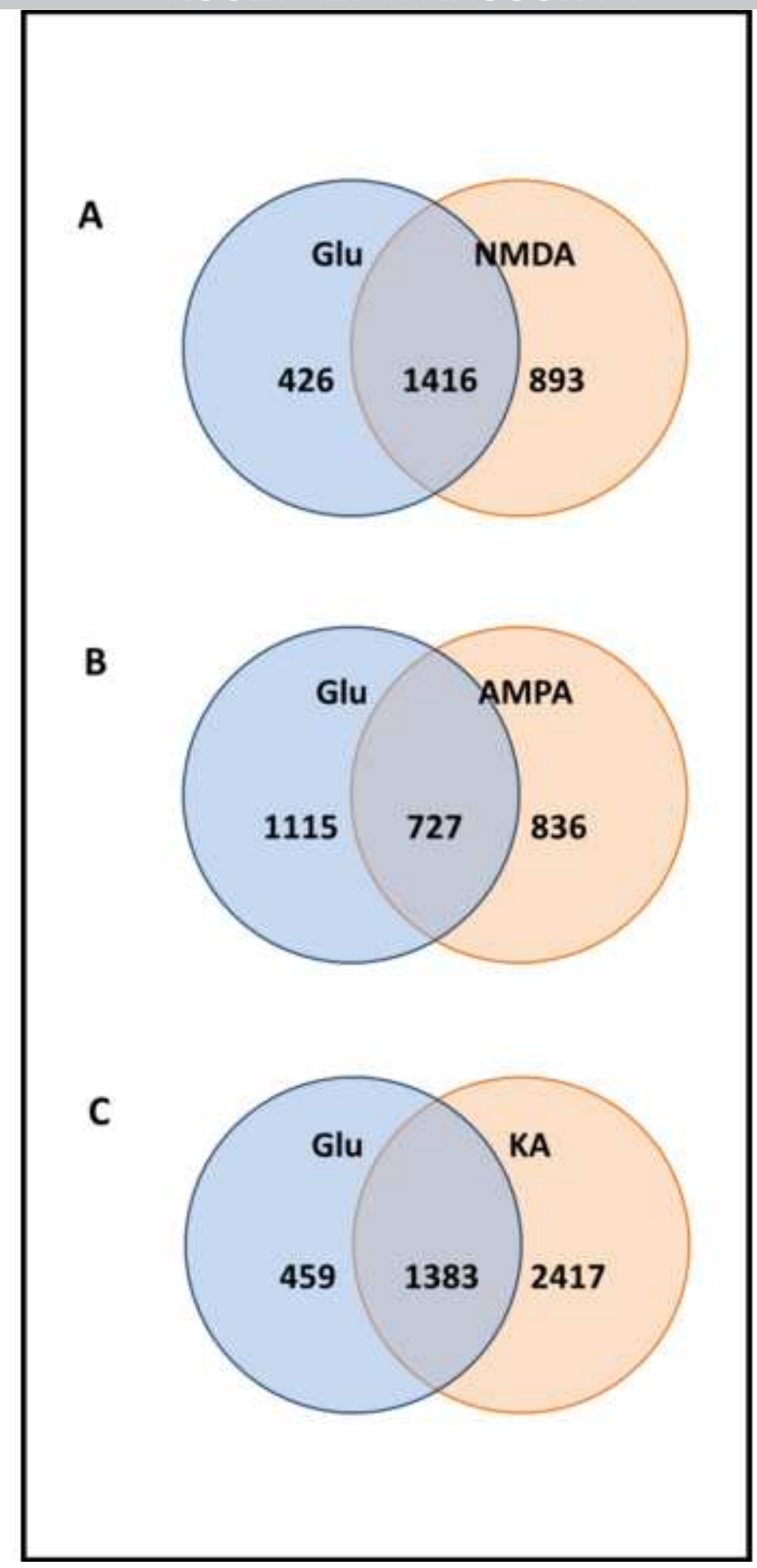

c

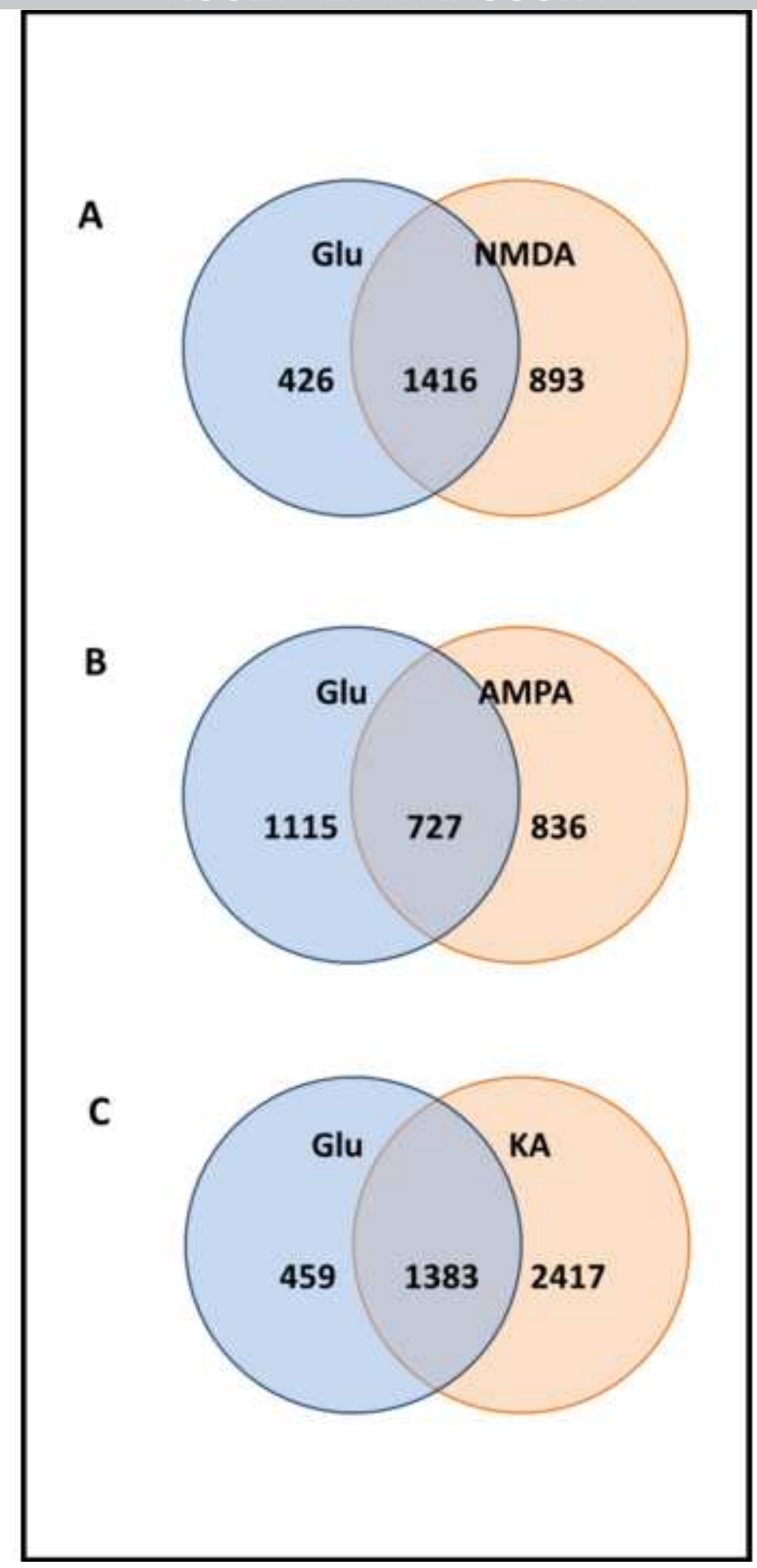

Figure 2 


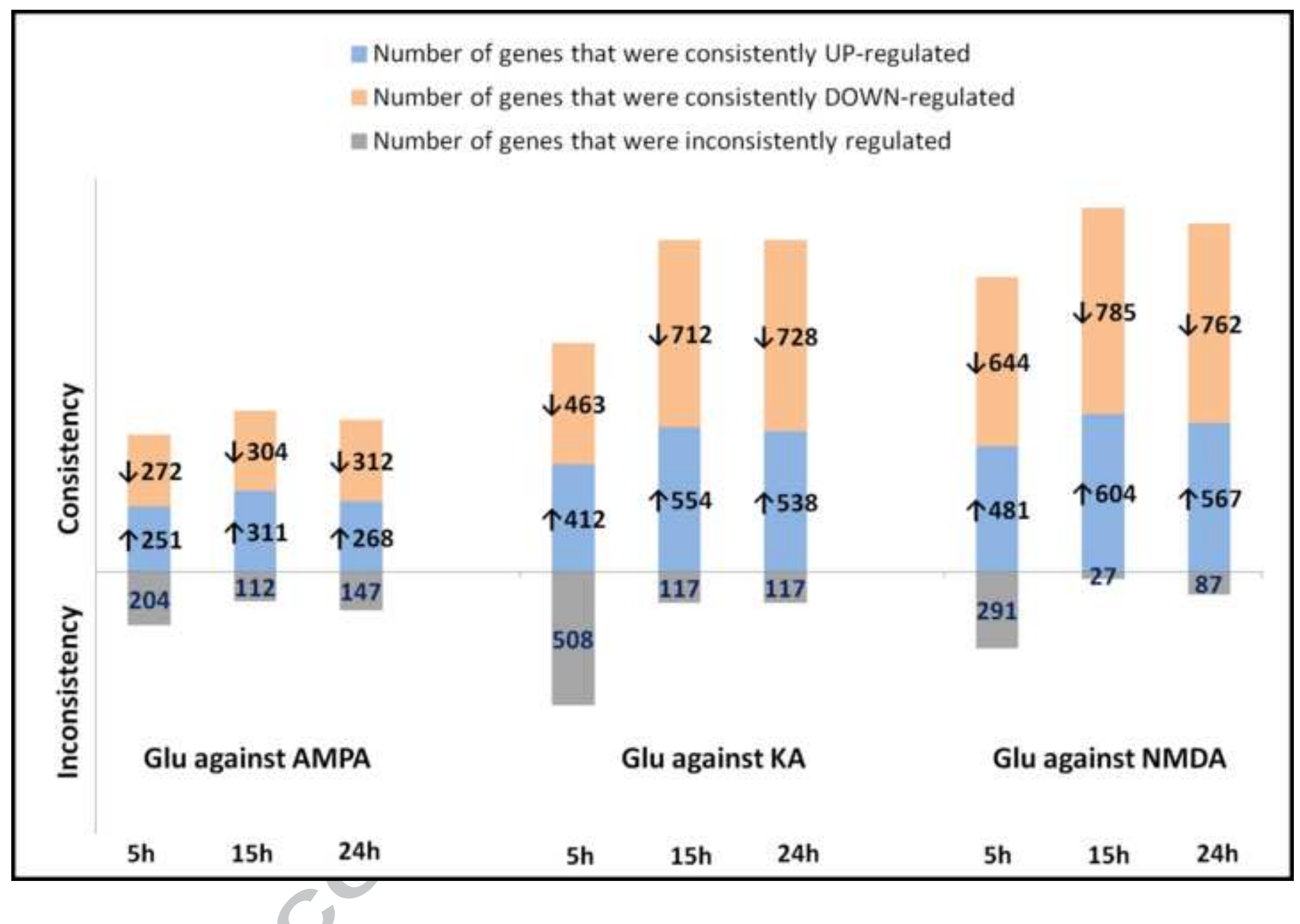

Number of genes that were consistently UP-regulated

tly DOWN-regulated

Number of genes that were inconsistently regulated 


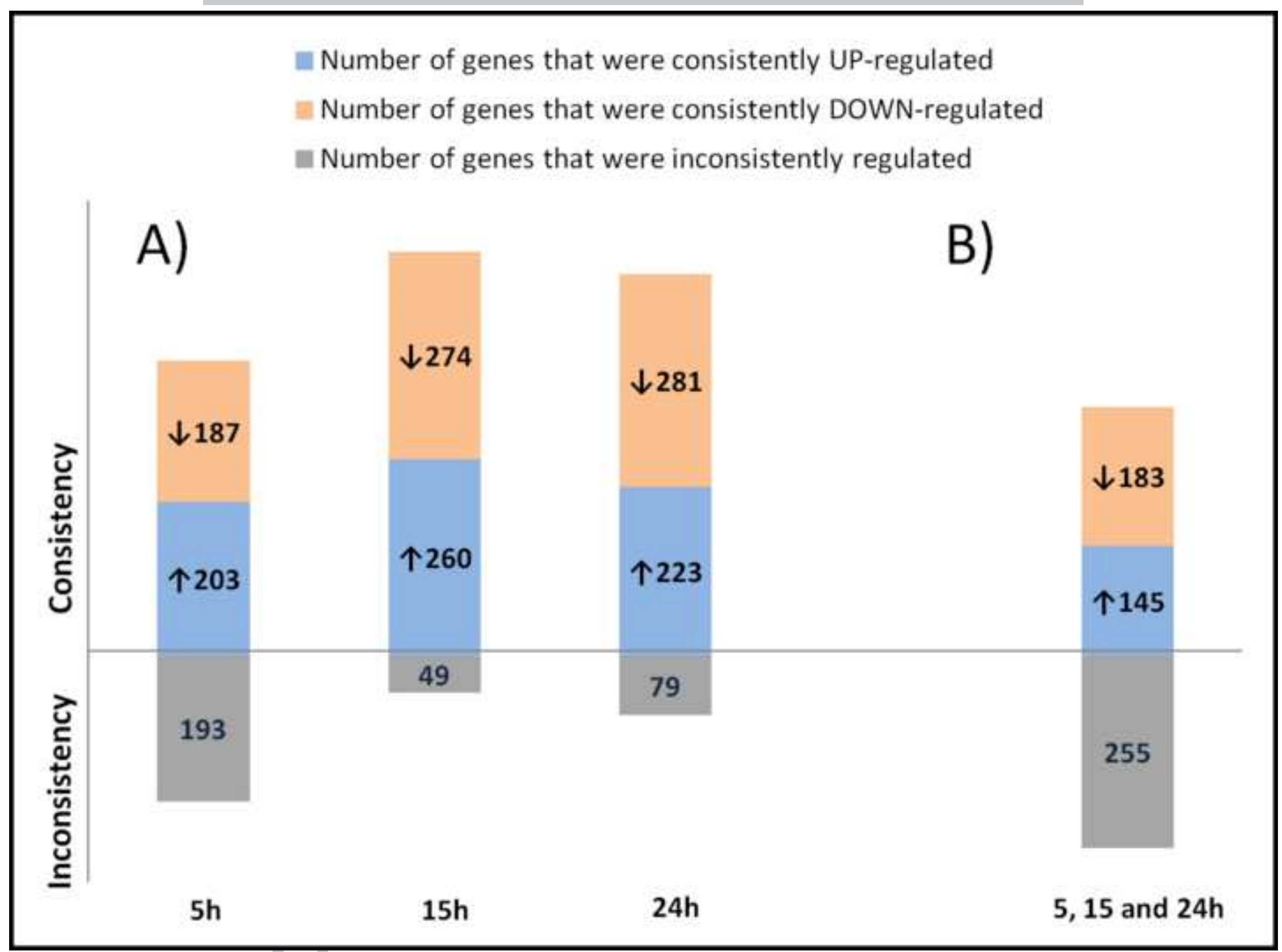

number of genes that were consistently DOWN-regulated

number of genes that were inconsistently regulated 


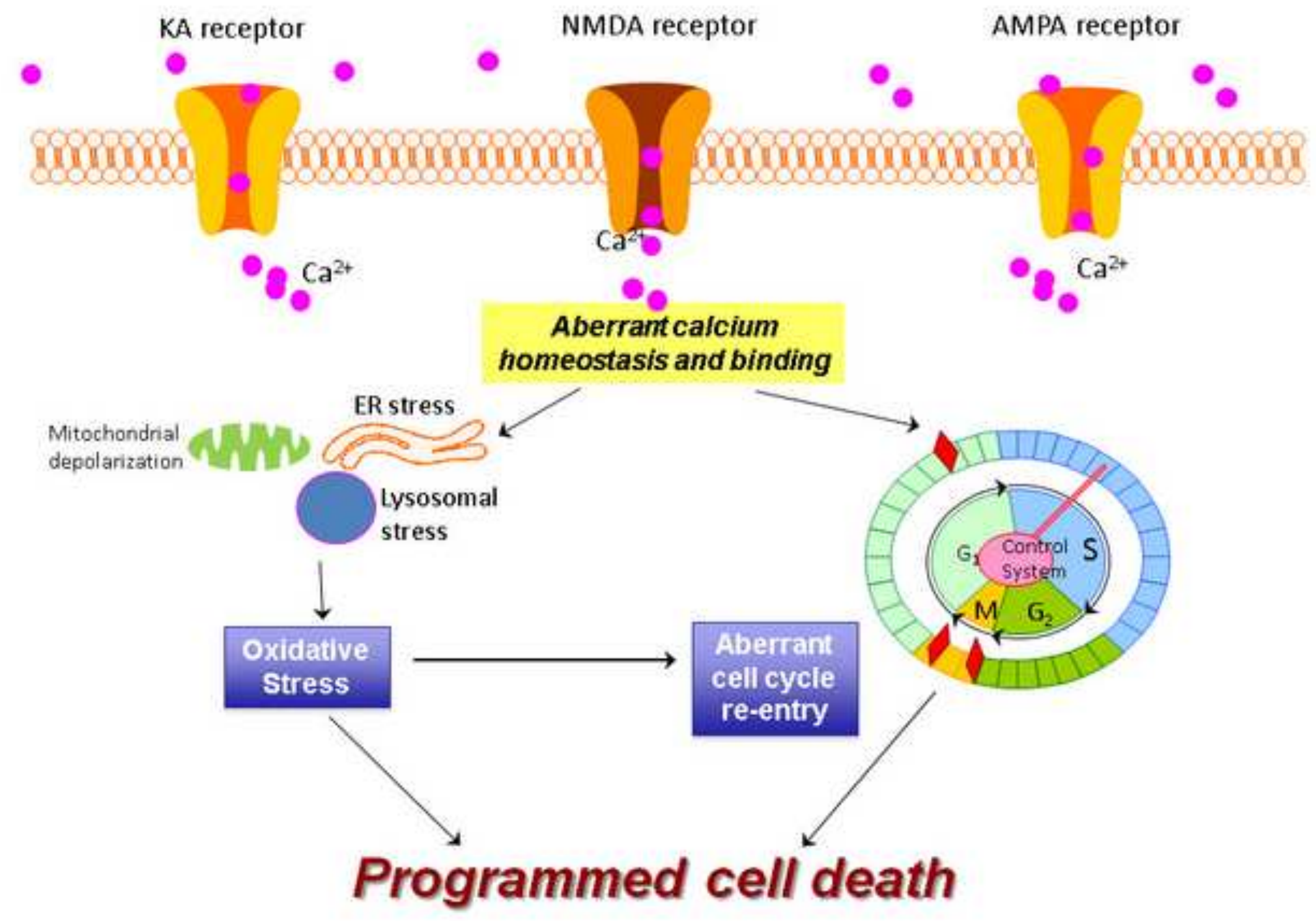

reptor

NMDA receptor 


\section{Tables}

Table 1. Gene expression profiles of neuronal death-related families in cultured mouse primary cortical neurons treated with EC 50 concentrations of AMPA, KA, NMDA and Glu over a 24-hour period respectively. All expression values (given as fold-changes) were selected based on having at least minimum of \pm 1.5 fold change in at least one out of three time-points, subjected to one-way ANOVA analysis and were significant at $p<0.05$. Values are given as mean \pm sem.

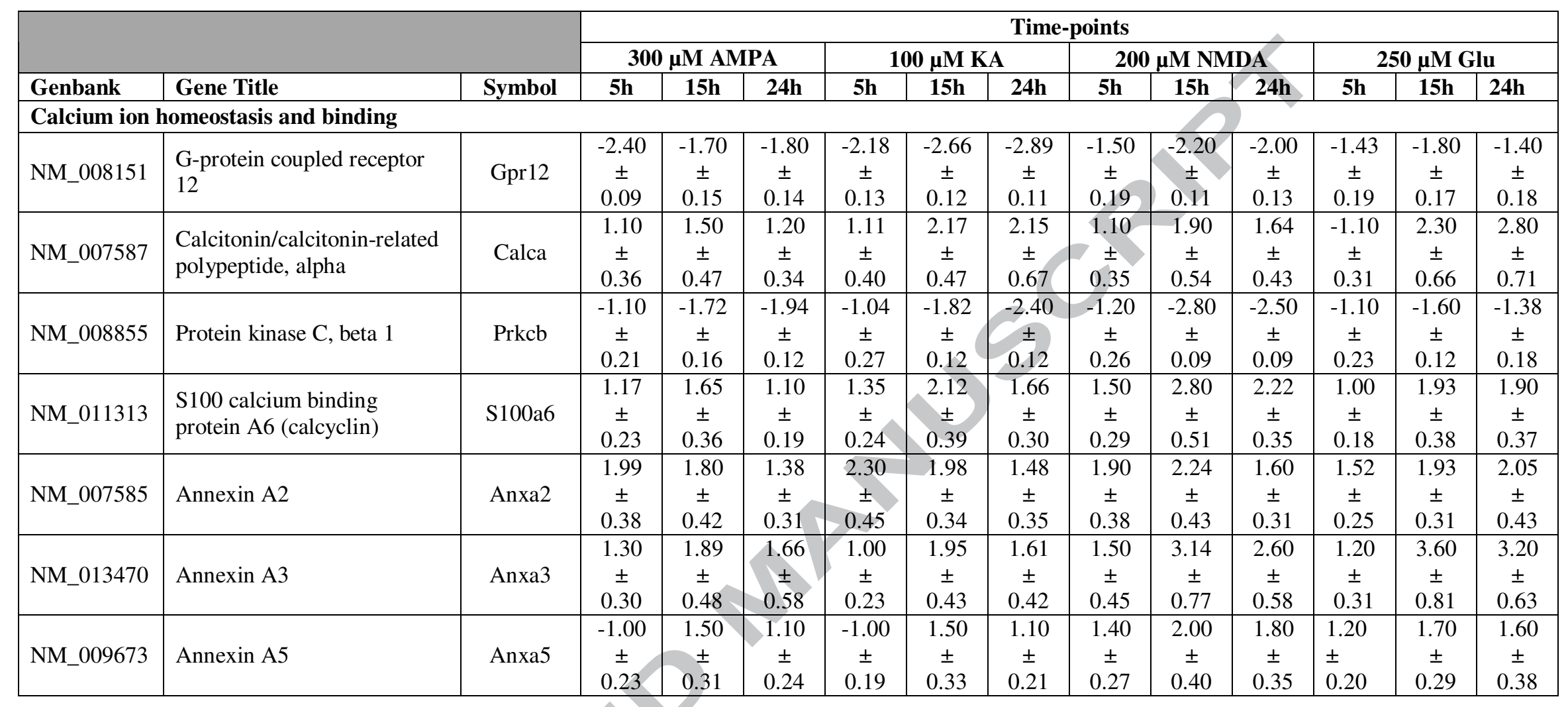


ACCEPTED MANUSCRIPT

\begin{tabular}{|c|c|c|c|c|c|c|c|c|c|c|c|c|c|c|}
\hline \multirow[b]{3}{*}{ Genbank } & \multirow[b]{3}{*}{ Gene Title } & \multirow[b]{3}{*}{ Symbol } & \multicolumn{12}{|c|}{ Time-points } \\
\hline & & & \multicolumn{3}{|c|}{ 300 $\mu \mathrm{M}$ AMPA } & \multicolumn{3}{|c|}{$100 \mu \mathrm{M}$ KA } & \multicolumn{3}{|c|}{$200 \mu M$ NMDA } & \multicolumn{3}{|c|}{$250 \mu \mathrm{M}$ Glu } \\
\hline & & & $\mathbf{5 h}$ & $15 \mathrm{~h}$ & $24 h$ & $\mathbf{5 h}$ & $15 \mathrm{~h}$ & $24 h$ & $5 \mathbf{h}$ & $15 \mathrm{~h}$ & $24 h$ & $5 \mathbf{h}$ & 15h & $24 \mathrm{~h}$ \\
\hline \multicolumn{15}{|c|}{ Lysosomal stress } \\
\hline NM_017372 & Lysozyme 2 & Lyz2 & $\begin{array}{c}1.63 \\
\pm \\
0.40\end{array}$ & $\begin{array}{c}1.42 \\
\pm \\
0.36\end{array}$ & $\begin{array}{c}-1.13 \\
\pm \\
0.24\end{array}$ & $\begin{array}{c}-1.10 \\
\pm \\
0.29\end{array}$ & $\begin{array}{c}1.50 \\
\pm \\
0.36\end{array}$ & $\begin{array}{c}1.40 \\
\pm \\
0.43\end{array}$ & $\begin{array}{c}1.60 \\
\pm \\
0.61\end{array}$ & $\begin{array}{c}2.10 \\
\pm \\
0.69\end{array}$ & $\begin{array}{c}2.10 \\
\pm \\
0.48\end{array}$ & $\begin{array}{c}1.20 \\
\pm \\
0.30\end{array}$ & $\begin{array}{c}1.65 \\
\pm \\
0.40\end{array}$ & $\begin{array}{c}1.50 \\
\pm \\
0.44\end{array}$ \\
\hline NM_010686 & $\begin{array}{l}\text { Lysosomal-associated } \\
\text { protein transmembrane } 5\end{array}$ & Laptm5 & $\begin{array}{c}1.70 \\
\pm \\
0.31\end{array}$ & $\begin{array}{c}1.40 \\
\pm \\
0.34\end{array}$ & $\begin{array}{c}-1.10 \\
\pm \\
0.19\end{array}$ & $\begin{array}{c}-1.50 \\
\pm \\
0.18\end{array}$ & $\begin{array}{c}1.80 \\
\pm \\
0.34\end{array}$ & $\begin{array}{c}1.40 \\
\pm \\
0.50\end{array}$ & $\begin{array}{c}1.71 \\
\pm \\
0.46\end{array}$ & $\begin{array}{c}2.31 \\
\pm \\
0.98\end{array}$ & $\begin{array}{c}2.13 \\
\pm \\
0.34\end{array}$ & $\begin{array}{c}1.34 \\
\pm \\
0.25\end{array}$ & $\begin{array}{c}1.98 \\
\pm \\
0.37\end{array}$ & $\begin{array}{c}1.95 \\
\pm \\
0.40\end{array}$ \\
\hline NM_010685 & $\begin{array}{l}\text { Lysosomal-associated } \\
\text { membrane protein } 2\end{array}$ & Lamp2 & $\begin{array}{c}1.38 \\
\pm \\
0.39\end{array}$ & $\begin{array}{c}1.60 \\
\pm \\
0.41\end{array}$ & $\begin{array}{c}1.30 \\
\pm \\
0.32\end{array}$ & $\begin{array}{c}1.63 \\
\pm \\
0.39\end{array}$ & $\begin{array}{c}2.23 \\
\pm \\
0.50\end{array}$ & $\begin{array}{c}1.54 \\
\pm \\
0.37\end{array}$ & $\begin{array}{c}1.44 \\
\pm \\
0.36\end{array}$ & $\begin{array}{c}2.31 \\
\pm \\
0.41\end{array}$ & $\begin{array}{c}1.77 \\
\pm \\
0.30\end{array}$ & $\begin{array}{c}-1.10 \\
\pm \\
0.30\end{array}$ & $\begin{array}{c}1.75 \\
\pm \\
0.51\end{array}$ & $\begin{array}{c}1.70 \\
\pm \\
0.38 \\
\end{array}$ \\
\hline NM_019972 & Sortilin 1 & Sort1 & $\begin{array}{c}1.10 \\
\pm \\
0.35\end{array}$ & $\begin{array}{c}1.28 \\
\pm \\
0.50\end{array}$ & $\begin{array}{c}1.22 \\
\pm \\
0.54\end{array}$ & $\begin{array}{c}1.50 \\
\pm \\
0.51\end{array}$ & $\begin{array}{c}2.31 \\
\pm \\
0.56\end{array}$ & $\begin{array}{c}1.80 \\
\pm \\
0.46\end{array}$ & $\begin{array}{c}1.50 \\
\pm \\
0.45\end{array}$ & $\begin{array}{c}3.70 \\
\pm \\
0.81\end{array}$ & $\begin{array}{c}2.50 \\
\pm \\
0.64\end{array}$ & $\begin{array}{c}1.50 \\
\pm \\
0.45\end{array}$ & $\begin{array}{c}2 . .00 \\
\pm \\
0.63\end{array}$ & $\begin{array}{c}1.40 \\
\pm \\
0.44\end{array}$ \\
\hline NM_009906 & Tripeptidyl peptidase I & Tpp1 & $\begin{array}{c}1.20 \\
\pm \\
0.29\end{array}$ & $\begin{array}{c}1.70 \\
\pm \\
0.53\end{array}$ & $\begin{array}{c}1.10 \\
\pm \\
0.30\end{array}$ & $\begin{array}{c}1.50 \\
\pm \\
0.40\end{array}$ & $\begin{array}{c}1.95 \\
\pm \\
0.53\end{array}$ & $\begin{array}{c}1.70 \\
\pm \\
0.54\end{array}$ & $\begin{array}{c}1.20 \\
\pm \\
0.36\end{array}$ & $\begin{array}{c}1.70 \\
\pm \\
0.40\end{array}$ & $\begin{array}{c}1.30 \\
\pm \\
0.31 \\
\end{array}$ & $\begin{array}{c}-1.10 \\
\pm \\
0.32\end{array}$ & $\begin{array}{c}1.60 \\
\pm \\
0.41\end{array}$ & $\begin{array}{c}1.60 \\
\pm \\
0.40\end{array}$ \\
\hline \multicolumn{15}{|c|}{ Anti-oxidant response - Heat shock proteins and molecular chaperones } \\
\hline NM_010442 & $\begin{array}{l}\text { Heme oxygenase (decycling) } \\
1\end{array}$ & Hmox 1 & $\begin{array}{c}2.32 \\
\pm \\
0.45\end{array}$ & $\begin{array}{c}1.68 \\
\pm \\
0.29\end{array}$ & $\begin{array}{c}1.38 \\
\pm \\
0.51\end{array}$ & $\begin{array}{c}2.34 \\
\pm \\
0.39 \\
\end{array}$ & $\begin{array}{c}2.17 \\
\pm \\
0.39\end{array}$ & $\begin{array}{c}2.04 \\
\pm \\
0.37\end{array}$ & $\begin{array}{c}2.70 \\
\pm \\
0.58\end{array}$ & $\begin{array}{c}3.11 \\
\pm \\
0.48\end{array}$ & $\begin{array}{c}1.60 \\
\pm \\
0.29\end{array}$ & $\begin{array}{c}1.60 \\
\pm \\
0.34\end{array}$ & $\begin{array}{c}2.37 \\
\pm \\
0.41\end{array}$ & $\begin{array}{c}1.51 \\
\pm \\
0.38 \\
\end{array}$ \\
\hline NM_029688 & $\begin{array}{l}\text { Sulfiredoxin } 1 \text { homolog }(\mathrm{S} . \\
\text { cerevisiae) }\end{array}$ & Srxn 1 & $\begin{array}{c}2.60 \\
\pm \\
0.56\end{array}$ & $\begin{array}{c}1.70 \\
\pm \\
0.34\end{array}$ & $\begin{array}{c}1.30 \\
\pm \\
0.41\end{array}$ & $\begin{array}{c}3.10 \\
\pm \\
0.54\end{array}$ & $\begin{array}{c}1.93 \\
\pm \\
0.36\end{array}$ & $\begin{array}{c}1.38 \\
\pm \\
0.30\end{array}$ & $\begin{array}{c}2.00 \\
\pm \\
0.39\end{array}$ & $\begin{array}{c}1.95 \\
\pm \\
0.28\end{array}$ & $\begin{array}{c}1.10 \\
\pm \\
0.19\end{array}$ & $\begin{array}{c}-1.20 \\
\pm \\
0.29\end{array}$ & $\begin{array}{c}2.16 \\
\pm \\
0.73\end{array}$ & $\begin{array}{c}1.17 \\
\pm \\
0.43\end{array}$ \\
\hline NM_007453 & Peroxiredoxin 6 & Prdx6 & $\begin{array}{c}1.32 \\
\pm \\
0.41\end{array}$ & $\begin{array}{c}1.72 \\
\pm \\
0.55\end{array}$ & $\begin{array}{c}1.16 \\
\pm \\
0.37\end{array}$ & $\begin{array}{c}1.10 \\
\pm \\
0.30\end{array}$ & $\begin{array}{c}1.30 \\
\pm \\
0.30\end{array}$ & $\begin{array}{c}1.25 \\
\pm \\
0.40\end{array}$ & $\begin{array}{c}1.14 \\
\pm \\
0.36\end{array}$ & $\begin{array}{c}1.62 \\
\pm \\
0.47\end{array}$ & $\begin{array}{c}1.20 \\
\pm \\
0.28\end{array}$ & $\begin{array}{c}-1.10 \\
\pm \\
0.27\end{array}$ & $\begin{array}{c}2.02 \\
\pm \\
0.60\end{array}$ & $\begin{array}{c}1.80 \\
\pm \\
0.56\end{array}$ \\
\hline NM_008301 & Heat shock protein 2 & Hspa2 & $\begin{array}{c}1.50 \\
\pm \\
0.44\end{array}$ & $\begin{array}{c}3.00 \\
\pm \\
0.76\end{array}$ & $\begin{array}{c}2.30 \\
\pm \\
0.64\end{array}$ & $\begin{array}{c}1.64 \\
\pm \\
0.44\end{array}$ & $\begin{array}{c}2.77 \\
\pm \\
0.65\end{array}$ & $\begin{array}{c}2.26 \\
\pm \\
0.64\end{array}$ & $\begin{array}{c}1.00 \\
\pm \\
0.26\end{array}$ & $\begin{array}{c}2.00 \\
\pm \\
0.52\end{array}$ & $\begin{array}{c}2.00 \\
\pm \\
0.47\end{array}$ & $\begin{array}{c}-1.30 \\
\pm \\
0.19\end{array}$ & $\begin{array}{c}1.64 \\
\pm \\
0.36\end{array}$ & $\begin{array}{c}1.60 \\
\pm \\
0.39 \\
\end{array}$ \\
\hline NM_030704 & Heat shock protein 8 & Hspb8 & $\begin{array}{c}1.80 \\
\pm \\
0.45\end{array}$ & $\begin{array}{c}2.20 \\
\pm \\
0.63\end{array}$ & $\begin{array}{c}1.40 \\
\pm \\
0.59\end{array}$ & $\begin{array}{c}1.42 \\
\pm \\
0.37\end{array}$ & $\begin{array}{c}2.61 \\
\pm \\
0.59\end{array}$ & $\begin{array}{c}1.60 \\
\pm \\
0.38\end{array}$ & $\begin{array}{c}2.00 \\
\pm \\
0.46\end{array}$ & $\begin{array}{c}3.90 \\
\pm \\
0.80\end{array}$ & $\begin{array}{c}1.83 \\
\pm \\
0.46\end{array}$ & $\begin{array}{c}1.29 \\
\pm \\
0.31\end{array}$ & $\begin{array}{c}4.40 \\
\pm \\
1.06\end{array}$ & $\begin{array}{c}2.63 \\
\pm \\
0.70\end{array}$ \\
\hline NM_013602 & Metallothionein 1 & & $\begin{array}{c}1.56 \\
\pm \\
0.28\end{array}$ & $\begin{array}{c}1.74 \\
\pm \\
0.28\end{array}$ & $\begin{array}{c}1.21 \\
\pm \\
0.17\end{array}$ & $\begin{array}{c}2.00 \\
\pm \\
0.40\end{array}$ & $\begin{array}{c}2.29 \\
\pm \\
0.38\end{array}$ & $\begin{array}{c}1.92 \\
\pm \\
0.38\end{array}$ & $\begin{array}{c}1.60 \\
\pm \\
0.25\end{array}$ & $\begin{array}{c}2.00 \\
\pm \\
0.34\end{array}$ & $\begin{array}{c}1.50 \\
\pm \\
0.24\end{array}$ & $\begin{array}{c}1.10 \\
\pm \\
0.16\end{array}$ & $\begin{array}{c}1.80 \\
\pm \\
0.26\end{array}$ & $\begin{array}{c}1.80 \\
\pm \\
0.39\end{array}$ \\
\hline NM_013603 & Metallothionein 3 & $\mathrm{Mt} 3$ & $\begin{array}{c}1.49 \\
\pm \\
0.26\end{array}$ & $\begin{array}{c}1.80 \\
\pm \\
0.69\end{array}$ & $\begin{array}{c}1.10 \\
\pm \\
0.20\end{array}$ & $\begin{array}{c}2.34 \\
\pm \\
0.48\end{array}$ & $\begin{array}{c}1.90 \\
\pm \\
0.34\end{array}$ & $\begin{array}{c}2.00 \\
\pm \\
0.49\end{array}$ & $\begin{array}{c}1.35 \\
\pm \\
0.27\end{array}$ & $\begin{array}{c}1.90 \\
\pm \\
0.27\end{array}$ & $\begin{array}{c}1.80 \\
\pm \\
0.55\end{array}$ & $\begin{array}{c}-1.10 \\
\pm \\
0.17\end{array}$ & $\begin{array}{c}1.60 \\
\pm \\
0.28\end{array}$ & $\begin{array}{c}1.60 \\
\pm \\
0.30\end{array}$ \\
\hline
\end{tabular}


ACCEPTED MANUSCRIPT

\begin{tabular}{|c|c|c|c|c|c|c|c|c|c|c|c|c|c|c|}
\hline \multirow[b]{3}{*}{ Genbank } & \multirow[b]{3}{*}{ Gene Title } & \multirow[b]{3}{*}{ Symbol } & \multicolumn{12}{|c|}{ Time-points } \\
\hline & & & \multicolumn{3}{|c|}{ 300 $\mu \mathrm{M}$ AMPA } & \multicolumn{3}{|c|}{$100 \mu \mathrm{M}$ KA } & \multicolumn{3}{|c|}{$200 \mu M$ NMDA } & \multicolumn{3}{|c|}{$250 \mu \mathrm{M}$ Glu } \\
\hline & & & $\mathbf{5 h}$ & $15 \mathrm{~h}$ & $24 h$ & $\mathbf{5 h}$ & 15h & 24h & $\mathbf{5 h}$ & 15h & $\mathbf{2 4 h}$ & $\mathbf{5 h}$ & 15h & $24 \mathrm{~h}$ \\
\hline \multicolumn{15}{|c|}{ Anti-oxidant response - Glutathione metabolism } \\
\hline NM_010357 & $\begin{array}{l}\text { Glutathione S-transferase, } \\
\text { alpha } 4\end{array}$ & Gsta4 & $\begin{array}{c}1.10 \\
\pm \\
0.29\end{array}$ & $\begin{array}{c}1.82 \\
\pm \\
0.44\end{array}$ & $\begin{array}{c}1.40 \\
\pm \\
0.33\end{array}$ & $\begin{array}{c}1.14 \\
\pm \\
0.31\end{array}$ & $\begin{array}{c}2.30 \\
\pm \\
0.60\end{array}$ & $\begin{array}{c}2.03 \\
\pm \\
0.48\end{array}$ & $\begin{array}{c}1.30 \\
\pm \\
0.39\end{array}$ & $\begin{array}{c}3.05 \\
\pm \\
0.70\end{array}$ & $\begin{array}{c}2.14 \\
\pm \\
0.52\end{array}$ & $\begin{array}{c}-1.20 \\
\pm \\
0.18\end{array}$ & $\begin{array}{c}2.60 \\
\pm \\
0.63\end{array}$ & $\begin{array}{c}2.10 \\
\pm \\
0.59\end{array}$ \\
\hline NM_008184 & $\begin{array}{l}\text { Glutathione S-transferase, } \\
\text { mu } 6\end{array}$ & Gstm6 & $\begin{array}{c}1.20 \\
\pm \\
0.40\end{array}$ & $\begin{array}{c}1.50 \\
\pm \\
0.53\end{array}$ & $\begin{array}{c}-1.00 \\
\pm \\
0.35\end{array}$ & $\begin{array}{c}1.50 \\
\pm \\
0.50\end{array}$ & $\begin{array}{c}1.90 \\
\pm \\
0.52\end{array}$ & $\begin{array}{c}1.20 \\
\pm \\
0.36\end{array}$ & $\begin{array}{c}1.45 \\
\pm \\
0.45\end{array}$ & $\begin{array}{c}2.10 \\
\pm \\
0.63\end{array}$ & $\begin{array}{c}1.34 \\
\pm \\
0.35\end{array}$ & $\begin{array}{c}-1.20 \\
\pm \\
0.22\end{array}$ & $\begin{array}{c}2.10 \\
\pm \\
0.58\end{array}$ & $\begin{array}{c}1.70 \\
\pm \\
0.52\end{array}$ \\
\hline NM_019946 & $\begin{array}{l}\text { Microsomal glutathione S- } \\
\text { transferase } 1\end{array}$ & Mgst1 & $\begin{array}{c}1.10 \\
\pm \\
0.30\end{array}$ & $\begin{array}{c}1.80 \\
\pm \\
0.46\end{array}$ & $\begin{array}{c}1.30 \\
\pm \\
0.42\end{array}$ & $\begin{array}{c}1.40 \\
\pm \\
0.44\end{array}$ & $\begin{array}{c}2.55 \\
\pm \\
0.53\end{array}$ & $\begin{array}{c}1.91 \\
\pm \\
0.51\end{array}$ & $\begin{array}{c}1.71 \\
\pm \\
0.42 \\
\end{array}$ & $\begin{array}{c}2.96 \\
\pm \\
0.60\end{array}$ & $\begin{array}{c}1.67 \\
\pm \\
0.37\end{array}$ & $\begin{array}{c}-1.00 \\
\pm \\
0.27\end{array}$ & $\begin{array}{c}3.20 \\
\pm \\
0.87\end{array}$ & $\begin{array}{c}2.90 \\
\pm \\
0.90\end{array}$ \\
\hline NM_025569 & $\begin{array}{l}\text { Microsomal glutathione S- } \\
\text { transferase } 3\end{array}$ & Mgst3 & $\begin{array}{c}-1.25 \\
\pm \\
0.19\end{array}$ & $\begin{array}{c}-1.56 \\
\pm \\
0.15\end{array}$ & $\begin{array}{c}-1.40 \\
\pm \\
0.16\end{array}$ & $\begin{array}{c}-1.20 \\
\pm \\
0.20\end{array}$ & $\begin{array}{c}-2.26 \\
\pm \\
0.09\end{array}$ & $\begin{array}{c}-2.14 \\
\pm \\
0.12\end{array}$ & $\begin{array}{c}-1.25 \\
\pm \\
0.18\end{array}$ & $\begin{array}{c}-2.00 \\
\pm \\
0.10\end{array}$ & $\begin{array}{c}-1.63 \\
\pm \\
0.12\end{array}$ & $\begin{array}{c}-1.30 \\
\pm \\
0.14\end{array}$ & $\begin{array}{c}-1.70 \\
\pm \\
0.11 \\
\end{array}$ & $\begin{array}{c}-1.60 \\
\pm \\
0.12\end{array}$ \\
\hline NM_010358 & $\begin{array}{l}\text { Glutathione S-transferase, } \\
\text { mu } 1\end{array}$ & Gstm1 & $\begin{array}{c}1.30 \\
\pm \\
0.26\end{array}$ & $\begin{array}{c}1.68 \\
\pm \\
0.27\end{array}$ & $\begin{array}{c}1.10 \\
\pm \\
0.18 \\
\end{array}$ & $\begin{array}{c}1.57 \\
\pm \\
0.33\end{array}$ & $\begin{array}{c}2.12 \\
\pm \\
0.40\end{array}$ & $\begin{array}{c}1.42 \\
\pm \\
0.40\end{array}$ & $\begin{array}{c}1.45 \\
\pm \\
0.32\end{array}$ & $\begin{array}{c}2.23 \\
\pm \\
0.46\end{array}$ & $\begin{array}{c}1.43 \\
\pm \\
0.30\end{array}$ & $\begin{array}{c}-1.10 \\
\pm \\
0.14\end{array}$ & $\begin{array}{c}1.90 \\
\pm \\
0.37\end{array}$ & $\begin{array}{c}1.64 \\
\pm \\
0.35\end{array}$ \\
\hline \multicolumn{15}{|l|}{ Cell death } \\
\hline NM_020581 & Angiopoietin-like 4 & Angptl4 & $\begin{array}{c}2.70 \\
\pm \\
0.59\end{array}$ & $\begin{array}{c}5.32 \\
\pm \\
1.14\end{array}$ & $\begin{array}{c}2.36 \\
\pm \\
0.63\end{array}$ & $\begin{array}{c}4.74 \\
\pm \\
0.84 \\
\end{array}$ & $\begin{array}{c}11.98 \\
\pm \\
2.14\end{array}$ & $\begin{array}{c}10.21 \\
\pm \\
2.28\end{array}$ & $\begin{array}{c}3.42 \\
\pm \\
0.65\end{array}$ & $\begin{array}{c}7.93 \\
\pm \\
1.61\end{array}$ & $\begin{array}{c}5.32 \\
\pm \\
1.00\end{array}$ & $\begin{array}{c}2.00 \\
\pm \\
0.46\end{array}$ & $\begin{array}{c}8.27 \\
\pm \\
1.62\end{array}$ & $\begin{array}{c}8.24 \\
\pm \\
1.58 \\
\end{array}$ \\
\hline NM_009811 & Caspase 6 & Casp6 & $\begin{array}{c}1.10 \\
\pm \\
0.28\end{array}$ & $\begin{array}{c}1.60 \\
\pm \\
0.33\end{array}$ & $\begin{array}{c}1.20 \\
\pm \\
0.32\end{array}$ & $\begin{array}{c}1.30 \\
\pm \\
0.30\end{array}$ & $\begin{array}{c}2.10 \\
\pm \\
0.35\end{array}$ & $\begin{array}{c}1.60 \\
\pm \\
0.36\end{array}$ & $\begin{array}{c}1.50 \\
\pm \\
0.39\end{array}$ & $\begin{array}{c}2.42 \\
\pm \\
0.48\end{array}$ & $\begin{array}{c}1.74 \\
\pm \\
0.27\end{array}$ & $\begin{array}{c}1.20 \\
\pm \\
0.31\end{array}$ & $\begin{array}{c}2.00 \\
\pm \\
0.37\end{array}$ & $\begin{array}{c}1.70 \\
\pm \\
0.46\end{array}$ \\
\hline NM_009818 & $\begin{array}{l}\text { Catenin (cadherin associated } \\
\text { protein), alpha } 1\end{array}$ & Ctnna1 & $\begin{array}{c}1.30 \\
\pm \\
0.21\end{array}$ & $\begin{array}{c}1.55 \\
\pm \\
0.24\end{array}$ & $\begin{array}{c}1.20 \\
\pm \\
0.18\end{array}$ & $\begin{array}{c}1.30 \\
\pm \\
0.23\end{array}$ & $\begin{array}{c}2.10 \\
\pm \\
0.29\end{array}$ & $\begin{array}{c}1.43 \\
\pm \\
0.27\end{array}$ & $\begin{array}{c}1.55 \\
\pm \\
0.28\end{array}$ & $\begin{array}{c}2.40 \\
\pm \\
0.33\end{array}$ & $\begin{array}{c}1.80 \\
\pm \\
0.32\end{array}$ & $\begin{array}{c}1.20 \\
\pm \\
0.20\end{array}$ & $\begin{array}{c}1.90 \\
\pm \\
0.34\end{array}$ & $\begin{array}{c}1.80 \\
\pm \\
0.36\end{array}$ \\
\hline NM_021399 & $\begin{array}{l}\text { B-cell leukemia/lymphoma } \\
\text { 11B }\end{array}$ & Bcl11b & $\begin{array}{c}-1.07 \\
\pm \\
0.17 \\
\end{array}$ & $\begin{array}{c}-1.80 \\
\pm \\
0.11\end{array}$ & $\begin{array}{c}-1.60 \\
\pm \\
0.12\end{array}$ & $\begin{array}{c}-1.37 \\
\pm \\
0.16\end{array}$ & $\begin{array}{c}-1.53 \\
\pm \\
0.12\end{array}$ & $\begin{array}{c}-1.82 \\
\pm \\
0.11\end{array}$ & $\begin{array}{c}-1.00 \\
\pm \\
0.21\end{array}$ & $\begin{array}{c}-2.20 \\
\pm \\
0.09\end{array}$ & $\begin{array}{c}-1.80 \\
\pm \\
0.11\end{array}$ & $\begin{array}{c}1.00 \\
\pm \\
0.17\end{array}$ & $\begin{array}{c}-1.70 \\
\pm \\
0.10\end{array}$ & $\begin{array}{c}-1.50 \\
\pm \\
0.12\end{array}$ \\
\hline
\end{tabular}


ACCEPTED MANUSCRIPT

\begin{tabular}{|c|c|c|c|c|c|c|c|c|c|c|c|c|c|c|}
\hline \multirow[b]{3}{*}{ Genbank } & \multirow[b]{3}{*}{ Gene Title } & \multirow[b]{3}{*}{ Symbol } & \multicolumn{12}{|c|}{ Time-points } \\
\hline & & & \multicolumn{3}{|c|}{ 300 $\mu \mathrm{M}$ AMPA } & \multicolumn{3}{|c|}{$100 \mu \mathrm{M}$ KA } & \multicolumn{3}{|c|}{$200 \mu M$ NMDA } & \multicolumn{3}{|c|}{$250 \mu \mathrm{M}$ Glu } \\
\hline & & & $\mathbf{5 h}$ & 15h & $\mathbf{2 4 h}$ & $\mathbf{5 h}$ & $15 \mathrm{~h}$ & 24h & $\mathbf{5 h}$ & 15h & $24 h$ & $5 \mathbf{h}$ & 15h & $24 \mathrm{~h}$ \\
\hline \multicolumn{15}{|c|}{ Cell homeostasis, survival and proliferation } \\
\hline NM_010835 & Homeobox, msh-like 1 & Msx 1 & $\begin{array}{c}1.17 \\
\pm \\
0.35\end{array}$ & $\begin{array}{c}1.65 \\
\pm \\
0.48\end{array}$ & $\begin{array}{c}1.00 \\
\pm \\
0.29\end{array}$ & $\begin{array}{c}1.90 \\
\pm \\
0.63\end{array}$ & $\begin{array}{c}2.02 \\
\pm \\
0.54\end{array}$ & $\begin{array}{c}1.82 \\
\pm \\
0.46\end{array}$ & $\begin{array}{c}1.25 \\
\pm \\
0.33\end{array}$ & $\begin{array}{c}1.60 \\
\pm \\
0.34\end{array}$ & $\begin{array}{c}1.45 \\
\pm \\
0.36\end{array}$ & $\begin{array}{c}-1.30 \\
\pm \\
0.25\end{array}$ & $\begin{array}{c}1.90 \\
\pm \\
0.57\end{array}$ & $\begin{array}{c}1.80 \\
\pm \\
0.47 \\
\end{array}$ \\
\hline NM_152229 & $\begin{array}{l}\text { Nuclear receptor subfamily } \\
2 \text {, group E, member } 1\end{array}$ & $\mathrm{Nr} 2 \mathrm{e} 1$ & $\begin{array}{c}1.40 \\
\pm \\
0.28\end{array}$ & $\begin{array}{c}1.80 \\
\pm \\
0.38\end{array}$ & $\begin{array}{c}1.30 \\
\pm \\
0.29\end{array}$ & $\begin{array}{c}1.90 \\
\pm \\
0.40\end{array}$ & $\begin{array}{c}2.30 \\
\pm \\
0.42\end{array}$ & $\begin{array}{c}1.70 \\
\pm \\
0.35\end{array}$ & $\begin{array}{c}1.40 \\
\pm \\
0.35\end{array}$ & $\begin{array}{c}2.00 \\
\pm \\
0.32 \\
\end{array}$ & $\begin{array}{c}1.60 \\
\pm \\
0.50 \\
\end{array}$ & $\begin{array}{c}1.00 \\
\pm \\
0.21\end{array}$ & $\begin{array}{c}2.00 \\
\pm \\
0.48\end{array}$ & $\begin{array}{c}2.10 \\
\pm \\
0.47\end{array}$ \\
\hline NM_009263 & Secreted phosphoprotein 1 & Spp1 & $\begin{array}{c}1.77 \\
\pm \\
0.40\end{array}$ & $\begin{array}{c}1.55 \\
\pm \\
0.38\end{array}$ & $\begin{array}{c}1.03 \\
\pm \\
0.28\end{array}$ & $\begin{array}{c}-1.00 \\
\pm \\
0.32\end{array}$ & $\begin{array}{c}2.43 \\
\pm \\
0.68\end{array}$ & $\begin{array}{c}2.23 \\
\pm \\
0.67\end{array}$ & $\begin{array}{c}1.90 \\
\pm \\
0.83\end{array}$ & $\begin{array}{c}3.50 \\
\pm \\
3.20\end{array}$ & $\begin{array}{c}4.30 \\
\pm \\
1.17\end{array}$ & $\begin{array}{c}1.20 \\
\pm \\
0.30\end{array}$ & $\begin{array}{c}2.00 \\
\pm \\
0.44\end{array}$ & $\begin{array}{c}2.00 \\
\pm \\
0.45\end{array}$ \\
\hline NM_009129 & Secretogranin II & $\operatorname{Scg} 2$ & $\begin{array}{c}10.12 \\
\pm \\
2.32 \\
\end{array}$ & $\begin{array}{c}11.74 \\
\pm \\
2.39\end{array}$ & $\begin{array}{c}9.17 \\
\pm \\
1.77\end{array}$ & $\begin{array}{c}11.00 \\
\pm \\
2.47\end{array}$ & $\begin{array}{c}14.06 \\
\pm \\
2.73 \\
\end{array}$ & $\begin{array}{c}12.03 \\
\pm \\
1.93\end{array}$ & $\begin{array}{c}1.94 \\
\pm \\
0.44\end{array}$ & $\begin{array}{c}2.44 \\
\pm \\
0.82\end{array}$ & $\begin{array}{c}4.03 \\
\pm \\
0.85\end{array}$ & $\begin{array}{c}1.00 \\
\pm \\
0.22\end{array}$ & $\begin{array}{c}-4.09 \\
\pm \\
0.07\end{array}$ & $\begin{array}{c}-3.79 \\
\pm \\
0.08\end{array}$ \\
\hline NM_009696 & Apolipoprotein E & Apoe & $\begin{array}{c}1.09 \\
\pm \\
0.23\end{array}$ & $\begin{array}{c}1.70 \\
\pm \\
0.29\end{array}$ & $\begin{array}{c}1.30 \\
\pm \\
0.24\end{array}$ & $\begin{array}{c}1.30 \\
\pm \\
0.28\end{array}$ & $\begin{array}{c}2.36 \\
\pm \\
0.43\end{array}$ & $\begin{array}{c}1.98 \\
\pm \\
0.36\end{array}$ & $\begin{array}{c}1.15 \\
\pm \\
0.27\end{array}$ & $\begin{array}{c}2.40 \\
\pm \\
0.52\end{array}$ & $\begin{array}{c}1.80 \\
\pm \\
0.27\end{array}$ & $\begin{array}{c}-1.20 \\
\pm \\
0.14\end{array}$ & $\begin{array}{c}1.70 \\
\pm \\
0.32\end{array}$ & $\begin{array}{c}1.70 \\
\pm \\
0.37\end{array}$ \\
\hline NM_009689 & $\begin{array}{l}\text { Baculoviral IAP repeat- } \\
\text { containing } 5\end{array}$ & Birc5 & $\begin{array}{c}1.94 \\
\pm \\
0.50\end{array}$ & $\begin{array}{c}1.25 \\
\pm \\
0.37\end{array}$ & $\begin{array}{c}-1.00 \\
\pm \\
0.26\end{array}$ & $\begin{array}{c}2.09 \\
\pm \\
0.59\end{array}$ & $\begin{array}{c}1.39 \\
\pm \\
0.35\end{array}$ & $\begin{array}{c}1.21 \\
\pm \\
0.31\end{array}$ & $\begin{array}{c}2.00 \\
\pm \\
0.56\end{array}$ & $\begin{array}{c}1.40 \\
\pm \\
0.33\end{array}$ & $\begin{array}{c}-1.00 \\
\pm \\
0.22\end{array}$ & $\begin{array}{c}1.54 \\
\pm \\
0.36\end{array}$ & $\begin{array}{c}1.88 \\
\pm \\
0.50\end{array}$ & $\begin{array}{c}1.34 \\
\pm \\
0.30\end{array}$ \\
\hline NM_013863 & $\begin{array}{l}\text { Bcl2-associated athanogene } \\
3\end{array}$ & Bag3 & $\begin{array}{c}1.80 \\
\pm \\
0.24\end{array}$ & $\begin{array}{c}2.40 \\
\pm \\
0.39\end{array}$ & $\begin{array}{c}2.40 \\
\pm \\
0.48\end{array}$ & $\begin{array}{c}2.50 \\
\pm \\
0.37\end{array}$ & $\begin{array}{c}2.49 \\
\pm \\
0.37 \\
\end{array}$ & $\begin{array}{c}2.09 \\
\pm \\
0.31 \\
\end{array}$ & $\begin{array}{c}2.30 \\
\pm \\
0.47\end{array}$ & $\begin{array}{c}2.70 \\
\pm \\
0.36\end{array}$ & $\begin{array}{c}2.50 \\
\pm \\
0.48\end{array}$ & $\begin{array}{c}1.60 \\
\pm \\
0.34\end{array}$ & $\begin{array}{c}2.00 \\
\pm \\
0.38\end{array}$ & $\begin{array}{c}1.80 \\
\pm \\
0.45\end{array}$ \\
\hline NM_010514 & Insulin-like growth factor 2 & $\operatorname{Igf} 2$ & $\begin{array}{c}1.40 \\
\pm \\
0.28\end{array}$ & $\begin{array}{c}1.50 \\
\pm \\
0.30\end{array}$ & $\begin{array}{c}1.00 \\
\pm \\
0.21\end{array}$ & $\begin{array}{c}1.80 \\
\pm \\
0.35\end{array}$ & $\begin{array}{c}2.10 \\
\pm \\
0.43\end{array}$ & $\begin{array}{c}1.60 \\
\pm \\
0.39\end{array}$ & $\begin{array}{c}1.60 \\
\pm \\
0.36\end{array}$ & $\begin{array}{c}1.70 \\
\pm \\
0.41\end{array}$ & $\begin{array}{c}1.30 \\
\pm \\
0.28\end{array}$ & $\begin{array}{c}1.60 \\
\pm \\
0.32\end{array}$ & $\begin{array}{c}2.40 \\
\pm \\
0.52\end{array}$ & $\begin{array}{c}2.10 \\
\pm \\
0.52\end{array}$ \\
\hline NM_133662 & Immediate early response 3 & Ier3 & $\begin{array}{c}1.40 \\
\pm \\
0.32 \\
\end{array}$ & $\begin{array}{c}1.40 \\
\pm \\
0.37 \\
\end{array}$ & $\begin{array}{c}1.80 \\
\pm \\
0.45\end{array}$ & $\begin{array}{c}-1.00 \\
\pm \\
0.26 \\
\end{array}$ & $\begin{array}{c}1.60 \\
\pm \\
0.31 \\
\end{array}$ & $\begin{array}{c}1.60 \\
\pm \\
0.35\end{array}$ & $\begin{array}{c}1.20 \\
\pm \\
0.32 \\
\end{array}$ & $\begin{array}{c}1.70 \\
\pm \\
0.31 \\
\end{array}$ & $\begin{array}{c}1.60 \\
\pm \\
0.27 \\
\end{array}$ & $\begin{array}{c}1.90 \\
\pm \\
0.48 \\
\end{array}$ & $\begin{array}{c}1.10 \\
\pm \\
0.34\end{array}$ & $\begin{array}{c}1.00 \\
\pm \\
0.21 \\
\end{array}$ \\
\hline NM_008520 & $\begin{array}{l}\text { Latent transforming growth } \\
\text { factor beta binding protein } 3\end{array}$ & Ltbp3 & $\begin{array}{c}1.10 \\
\pm \\
0.25\end{array}$ & $\begin{array}{c}1.80 \\
\pm \\
0.43\end{array}$ & $\begin{array}{c}1.60 \\
\pm \\
0.32 \\
\end{array}$ & $\begin{array}{c}1.05 \\
\pm \\
0.33\end{array}$ & $\begin{array}{c}1.23 \\
\pm \\
0.41\end{array}$ & $\begin{array}{c}1.38 \\
\pm \\
0.41\end{array}$ & $\begin{array}{c}1.20 \\
\pm \\
0.26\end{array}$ & $\begin{array}{c}1.60 \\
\pm \\
0.34\end{array}$ & $\begin{array}{c}1.80 \\
\pm \\
0.35\end{array}$ & $\begin{array}{c}-1.00 \\
\pm \\
0.22\end{array}$ & $\begin{array}{c}1.50 \\
\pm \\
0.25\end{array}$ & $\begin{array}{c}1.90 \\
\pm \\
0.41\end{array}$ \\
\hline NM_010518 & $\begin{array}{l}\text { Insulin-like growth factor } \\
\text { binding protein } 5\end{array}$ & Igfbp & $\begin{array}{c}-1.10 \\
\pm \\
0.25 \\
\end{array}$ & $\begin{array}{c}1.60 \\
\pm \\
0.32\end{array}$ & $\begin{array}{c}1.10 \\
\pm \\
0.26\end{array}$ & $\begin{array}{c}1.30 \\
\pm \\
0.26 \\
\end{array}$ & $\begin{array}{c}2.14 \\
\pm \\
0.38 \\
\end{array}$ & $\begin{array}{c}1.61 \\
\pm \\
0.40\end{array}$ & $\begin{array}{c}1.10 \\
\pm \\
0.25\end{array}$ & $\begin{array}{c}2.00 \\
\pm \\
0.40\end{array}$ & $\begin{array}{c}1.80 \\
\pm \\
0.39 \\
\end{array}$ & $\begin{array}{c}-1.20 \\
\pm \\
0.12 \\
\end{array}$ & $\begin{array}{c}1.70 \\
\pm \\
0.28\end{array}$ & $\begin{array}{c}1.90 \\
\pm \\
0.40 \\
\end{array}$ \\
\hline
\end{tabular}


ACCEPTED MANUSCRIPT

\begin{tabular}{|c|c|c|c|c|c|c|c|c|c|c|c|c|c|c|}
\hline \multirow[b]{3}{*}{ Genbank } & \multirow[b]{3}{*}{ Gene Title } & \multirow[b]{3}{*}{ Symbol } & \multicolumn{12}{|c|}{$\begin{array}{c}\text { Time-points } \\
\end{array}$} \\
\hline & & & \multicolumn{3}{|c|}{ 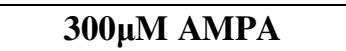 } & \multicolumn{3}{|c|}{$100 \mu \mathrm{M}$ KA } & \multicolumn{3}{|c|}{$200 \mu \mathrm{M}$ NMDA } & \multicolumn{3}{|c|}{$250 \mu \mathrm{M}$ Glu } \\
\hline & & & $5 \mathbf{h h}$ & $15 \mathrm{~h}$ & 24h & $5 \mathbf{5 h}$ & $15 \mathrm{~h}$ & 24h & $5 \mathrm{~h}$ & $15 \mathrm{~h}$ & 24h & $5 \mathbf{h h}$ & $15 \mathrm{~h}$ & $24 h$ \\
\hline NM_021099 & Kit oncogene & Kit & $\begin{array}{c}-2.12 \\
\pm \\
0.10\end{array}$ & $\begin{array}{l}-1.19 \\
\pm \\
0.20\end{array}$ & $\begin{array}{l}-1.15 \\
\pm \\
0.18\end{array}$ & $\begin{array}{l}-1.84 \\
\pm \\
0.11\end{array}$ & $\begin{array}{c}-2.90 \\
\pm \\
0.07\end{array}$ & $\begin{array}{c}-2.40 \\
\pm \\
0.10\end{array}$ & $\begin{array}{l}-1.50 \\
\pm \\
0.13\end{array}$ & $\begin{array}{l}-2.10 \\
\pm \\
0.10\end{array}$ & $\begin{array}{l}-1.20 \\
\pm \\
0.18\end{array}$ & $\begin{array}{l}-1.50 \\
\pm \\
0.12\end{array}$ & $\begin{array}{l}-1.70 \\
\pm \\
0.12\end{array}$ & $\begin{array}{l}-1.50 \\
\pm \\
0.17\end{array}$ \\
\hline \multicolumn{15}{|c|}{ Mitotic cell cycle } \\
\hline NM_025565 & $\begin{array}{l}\text { SPC25, NDC80 kinetochore } \\
\text { complex component, } \\
\text { homolog (S. cerevisiae) }\end{array}$ & Spc25 & $\begin{array}{c}1.79 \\
\pm \\
0.52 \\
\end{array}$ & $\begin{array}{c}1.50 \\
\pm \\
0.52 \\
\end{array}$ & $\begin{array}{c}-1.08 \\
\pm \\
0.32 \\
\end{array}$ & $\begin{array}{c}2.40 \\
\pm \\
0.81 \\
\end{array}$ & $\begin{array}{c}1.83 \\
\pm \\
0.57 \\
\end{array}$ & $\begin{array}{c}1.34 \\
\pm \\
0.45\end{array}$ & $\begin{array}{c}2.11 \\
\pm \\
0.48\end{array}$ & $\begin{array}{c}1.82 \\
\pm \\
0.49 \\
\end{array}$ & $\begin{array}{c}1.21 \\
\pm \\
0.32 \\
\end{array}$ & $\begin{array}{c}1.66 \\
\pm \\
0.41 \\
\end{array}$ & $\begin{array}{c}1.85 \\
\pm \\
0.65\end{array}$ & $\begin{array}{c}1.47 \\
\pm \\
0.63 \\
\end{array}$ \\
\hline NM_028390 & Anillin, actin binding protein & Anln & $\begin{array}{c}1.97 \\
\pm \\
0.51\end{array}$ & $\begin{array}{c}1.28 \\
\pm \\
0.28\end{array}$ & $\begin{array}{c}-1.10 \\
\pm \\
0.19\end{array}$ & $\begin{array}{c}1.96 \\
\pm \\
0.48\end{array}$ & $\begin{array}{c}1.60 \\
\pm \\
0.35\end{array}$ & $\begin{array}{c}1.19 \\
\pm \\
0.32\end{array}$ & $\begin{array}{c}1.84 \\
\pm \\
0.41\end{array}$ & $\begin{array}{c}1.50 \\
\pm \\
0.33\end{array}$ & $\begin{array}{c}1.18 \\
\pm \\
0.26\end{array}$ & $\begin{array}{c}1.80 \\
\pm \\
0.40\end{array}$ & $\begin{array}{c}1.86 \\
\pm \\
0.51\end{array}$ & $\begin{array}{c}1.67 \\
\pm \\
0.41 \\
\end{array}$ \\
\hline NM_011497 & Aurora kinase A & Aurka & $\begin{array}{c}2.31 \\
\pm \\
0.56\end{array}$ & $\begin{array}{c}1.48 \\
\pm \\
0.36\end{array}$ & $\begin{array}{c}1.04 \\
\pm \\
0.25\end{array}$ & $\begin{array}{c}2.30 \\
\pm \\
0.55\end{array}$ & $\begin{array}{c}1.46 \\
\pm \\
0.37\end{array}$ & $\begin{array}{c}1.07 \\
\pm \\
0.29\end{array}$ & $\begin{array}{c}1.65 \\
\pm \\
0.40\end{array}$ & $\begin{array}{c}1.31 \\
\pm \\
0.32\end{array}$ & $\begin{array}{c}1.11 \\
\pm \\
0.26\end{array}$ & $\begin{array}{c}1.91 \\
\pm \\
0.42\end{array}$ & $\begin{array}{c}1.98 \\
\pm \\
0.50\end{array}$ & $\begin{array}{c}1.59 \\
\pm \\
0.44\end{array}$ \\
\hline NM_028109 & $\begin{array}{l}\text { TPX2, microtubule- } \\
\text { associated protein homolog } \\
\text { (Xenopus laevis) }\end{array}$ & Tpx2 & $\begin{array}{l}1.80 \\
\pm \\
0.46\end{array}$ & $\begin{array}{c}1.27 \\
\pm \\
0.41\end{array}$ & $\begin{array}{c}-1.08 \\
\pm \\
0.26\end{array}$ & $\begin{array}{c}1.90 \\
\pm \\
0.49\end{array}$ & $\begin{array}{c}1.49 \\
\pm \\
0.45\end{array}$ & $\begin{array}{c}1.06 \\
\pm \\
0.35\end{array}$ & $\begin{array}{c}1.80 \\
\pm \\
0.49\end{array}$ & $\begin{array}{l}1.50 \\
\pm \\
0.33\end{array}$ & $\begin{array}{l}1.10 \\
\pm \\
0.25\end{array}$ & $\begin{array}{c}1.70 \\
\pm \\
0.42\end{array}$ & $\begin{array}{l}2.09 \\
\pm \\
0.55\end{array}$ & $\begin{array}{c}1.57 \\
\pm \\
0.46\end{array}$ \\
\hline NM_007659 & Cyclin-dependent kinase 1 & Cdk1 & $\begin{array}{c}2.58 \\
\pm \\
0.62\end{array}$ & $\begin{array}{c}1.54 \\
\pm \\
0.45\end{array}$ & $\begin{array}{c}-1.10 \\
\pm \\
0.26\end{array}$ & $\begin{array}{l}3.02 \\
\pm \\
0.71\end{array}$ & $\begin{array}{c}1.74 \\
\pm \\
0.38\end{array}$ & $\begin{array}{c}1.18 \\
\pm \\
0.32\end{array}$ & $\begin{array}{l}2.10 \\
\pm \\
0.51\end{array}$ & $\begin{array}{c}1.66 \\
\pm \\
0.39\end{array}$ & $\begin{array}{c}1.19 \\
\pm \\
0.26\end{array}$ & $\begin{array}{l}2.06 \\
\pm \\
0.42\end{array}$ & $\begin{array}{c}1.91 \\
\pm \\
0.47\end{array}$ & $\begin{array}{c}1.50 \\
\pm \\
0.39\end{array}$ \\
\hline NM_023223 & $\begin{array}{l}\text { Cell division cycle } 20 \\
\text { homolog (S. cerevisiae) }\end{array}$ & $\mathrm{Cdc} 20$ & $\begin{array}{c}1.53 \\
\pm \\
0.50\end{array}$ & $\begin{array}{c}1.06 \\
\pm \\
0.38\end{array}$ & $\begin{array}{c}-1.15 \\
\pm \\
0.24\end{array}$ & $\begin{array}{c}1.51 \\
\pm \\
0.55\end{array}$ & $\begin{array}{c}1.35 \\
\pm \\
0.50\end{array}$ & $\begin{array}{c}1.04 \\
\pm \\
0.46\end{array}$ & $\begin{array}{c}1.87 \\
\pm \\
0.39\end{array}$ & $\begin{array}{c}1.43 \\
\pm \\
0.31\end{array}$ & $\begin{array}{c}-1.02 \\
\pm \\
0.24\end{array}$ & $\begin{array}{c}1.61 \\
\pm \\
0.41\end{array}$ & $\begin{array}{c}2.03 \\
\pm \\
0.50\end{array}$ & $\begin{array}{c}1.32 \\
\pm \\
0.36\end{array}$ \\
\hline NM_013538 & $\begin{array}{l}\text { Cell division cycle } \\
\text { associated } 3\end{array}$ & Cdca3 & $\begin{array}{c}2.17 \\
\pm \\
0.65\end{array}$ & $\begin{array}{c}1.45 \\
\pm \\
0.45\end{array}$ & $\begin{array}{c}1.00 \\
\pm \\
0.28\end{array}$ & $\begin{array}{c}1.94 \\
\pm \\
0.55\end{array}$ & $\begin{array}{c}1.96 \\
\pm \\
0.56\end{array}$ & $\begin{array}{c}1.34 \\
\pm \\
0.41\end{array}$ & $\begin{array}{c}2.18 \\
\pm \\
0.62\end{array}$ & $\begin{array}{c}1.78 \\
\pm \\
0.42\end{array}$ & $\begin{array}{c}1.04 \\
\pm \\
0.26\end{array}$ & $\begin{array}{c}1.57 \\
\pm \\
0.39\end{array}$ & $\begin{array}{c}2.03 \\
\pm \\
0.48\end{array}$ & $\begin{array}{c}1.43 \\
\pm \\
0.39\end{array}$ \\
\hline NM_172301 & Cyclin B1 & Ccnb1 & $\begin{array}{c}2.75 \\
\pm \\
0.63\end{array}$ & $\begin{array}{c}1.66 \\
\pm \\
0.40 \\
\end{array}$ & $\begin{array}{c}1.00 \\
\pm \\
0.30 \\
\end{array}$ & $\begin{array}{c}3.13 \\
\pm \\
0.82\end{array}$ & $\begin{array}{c}1.85 \\
\pm \\
0.60\end{array}$ & $\begin{array}{c}1.42 \\
\pm \\
0.43\end{array}$ & $\begin{array}{c}2.07 \\
\pm \\
0.50\end{array}$ & $\begin{array}{c}1.62 \\
\pm \\
0.41\end{array}$ & $\begin{array}{c}1.19 \\
\pm \\
0.29\end{array}$ & $\begin{array}{c}1.68 \\
\pm \\
0.42\end{array}$ & $\begin{array}{c}2.09 \\
\pm \\
0.54\end{array}$ & $\begin{array}{c}1.48 \\
\pm \\
0.51 \\
\end{array}$ \\
\hline NM_009831 & Cyclin G1 & Ccng1 & $\begin{array}{c}1.30 \\
\pm \\
0.32\end{array}$ & $\begin{array}{c}1.47 \\
\pm \\
0.49\end{array}$ & $\begin{array}{c}1.12 \\
\pm \\
0.23\end{array}$ & $\begin{array}{c}1.53 \\
\pm \\
0.47\end{array}$ & $\begin{array}{c}1.35 \\
\pm \\
0.36\end{array}$ & $\begin{array}{c}-1.01 \\
\pm \\
0.27\end{array}$ & $\begin{array}{c}1.30 \\
\pm \\
0.34\end{array}$ & $\begin{array}{c}1.55 \\
\pm \\
0.33\end{array}$ & $\begin{array}{c}1.25 \\
\pm \\
0.34\end{array}$ & $\begin{array}{c}1.36 \\
\pm \\
0.31\end{array}$ & $\begin{array}{c}1.52 \\
\pm \\
0.39\end{array}$ & $\begin{array}{c}1.31 \\
\pm \\
0.29\end{array}$ \\
\hline NM_031166 & Inhibitor of DNA binding 4 & & $\begin{array}{c}1.27 \\
\pm \\
0.38\end{array}$ & $\begin{array}{c}1.65 \\
\pm \\
0.48\end{array}$ & $\begin{array}{c}1.07 \\
\pm \\
0.28\end{array}$ & $\begin{array}{c}1.57 \\
\pm \\
0.47\end{array}$ & $\begin{array}{c}2.20 \\
\pm \\
0.65\end{array}$ & $\begin{array}{c}1.70 \\
\pm \\
0.59\end{array}$ & $\begin{array}{c}1.36 \\
\pm \\
0.41\end{array}$ & $\begin{array}{c}1.89 \\
\pm \\
0.53\end{array}$ & $\begin{array}{c}1.15 \\
\pm \\
0.34\end{array}$ & $\begin{array}{c}-1.41 \\
\pm \\
0.21\end{array}$ & $\begin{array}{c}1.93 \\
\pm \\
0.56\end{array}$ & $\begin{array}{c}2.11 \\
\pm \\
0.76\end{array}$ \\
\hline
\end{tabular}


ACCEPTED MANUSCRIPT

\begin{tabular}{|c|c|c|c|c|c|c|c|c|c|c|c|c|c|c|}
\hline \multirow[b]{3}{*}{ Genbank } & \multirow[b]{3}{*}{ Gene Title } & \multirow[b]{3}{*}{ Symbol } & \multicolumn{12}{|c|}{ Time-points } \\
\hline & & & \multicolumn{3}{|c|}{ 300 $\mu$ M AMPA } & \multicolumn{3}{|c|}{$100 \mu \mathrm{M} \mathrm{KA}$} & \multicolumn{3}{|c|}{ 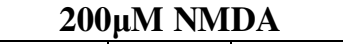 } & \multicolumn{3}{|c|}{$250 \mu \mathrm{M}$ Glu } \\
\hline & & & $5 \mathrm{~h}$ & $15 \mathrm{~h}$ & $24 h$ & $5 \mathrm{~h}$ & $15 \mathrm{~h}$ & 24h & $5 \mathrm{~h}$ & $15 \mathrm{~h}$ & $24 \mathrm{~h}$ & $5 \mathbf{h}$ & $15 \mathrm{~h}$ & $24 h$ \\
\hline NM_010578 & $\begin{array}{l}\text { Integrin beta } 1 \text { (fibronectin } \\
\text { receptor beta) }\end{array}$ & Itgb1 & $\begin{array}{c}1.58 \\
\pm \\
0.33\end{array}$ & $\begin{array}{c}1.29 \\
\pm \\
0.23\end{array}$ & $\begin{array}{c}1.13 \\
\pm \\
0.22\end{array}$ & $\begin{array}{c}1.59 \\
\pm \\
0.30\end{array}$ & $\begin{array}{c}1.64 \\
\pm \\
0.31\end{array}$ & $\begin{array}{c}1.13 \\
\pm \\
0.23\end{array}$ & $\begin{array}{c}1.54 \\
\pm \\
0.31\end{array}$ & $\begin{array}{c}1.45 \\
\pm \\
0.29\end{array}$ & $\begin{array}{c}1.10 \\
\pm \\
0.20\end{array}$ & $\begin{array}{c}1.34 \\
\pm \\
0.22\end{array}$ & $\begin{array}{c}1.64 \\
\pm \\
0.28\end{array}$ & $\begin{array}{c}1.46 \\
\pm \\
0.32\end{array}$ \\
\hline NM_023317 & $\begin{array}{l}\text { Nuclear distribution gene } \mathrm{E} \\
\text { homolog } 1 \text { (A nidulans) }\end{array}$ & Nde1 & $\begin{array}{c}1.40 \\
\pm \\
0.39\end{array}$ & $\begin{array}{c}1.74 \\
\pm \\
0.45\end{array}$ & $\begin{array}{c}1.11 \\
\pm \\
0.27\end{array}$ & $\begin{array}{c}1.58 \\
\pm \\
0.42\end{array}$ & $\begin{array}{c}1.89 \\
\pm \\
0.47\end{array}$ & $\begin{array}{c}1.57 \\
\pm \\
0.45\end{array}$ & $\begin{array}{c}1.28 \\
\pm \\
0.32\end{array}$ & $\begin{array}{c}1.56 \\
\pm \\
0.35\end{array}$ & $\begin{array}{c}1.24 \\
\pm \\
0.30\end{array}$ & $\begin{array}{c}1.13 \\
\pm \\
0.30\end{array}$ & $\begin{array}{c}1.77 \\
\pm \\
0.43\end{array}$ & $\begin{array}{c}1.35 \\
\pm \\
0.35\end{array}$ \\
\hline NM_007595 & $\begin{array}{l}\text { Calcium/calmodulin- } \\
\text { dependent protein kinase II, } \\
\text { beta }\end{array}$ & Camk2b & $\begin{array}{c}-1.04 \\
\pm \\
0.16\end{array}$ & $\begin{array}{c}-1.57 \\
\pm \\
0.13\end{array}$ & $\begin{array}{c}-1.52 \\
\pm \\
0.11\end{array}$ & $\begin{array}{c}1.00 \\
\pm \\
0.16\end{array}$ & $\begin{array}{c}-2.10 \\
\pm \\
0.08\end{array}$ & $\begin{array}{c}-2.30 \\
\pm \\
0.10\end{array}$ & $\begin{array}{c}-1.31 \\
\pm \\
0.13\end{array}$ & $\begin{array}{c}-2.47 \\
\pm \\
0.06\end{array}$ & $\begin{array}{c}-1.71 \\
\pm \\
0.11\end{array}$ & $\begin{array}{l}-1.18 \\
\pm \\
0.13\end{array}$ & $\begin{array}{c}-2.33 \\
\pm \\
0.09\end{array}$ & $\begin{array}{c}-1.74 \\
\pm \\
0.11\end{array}$ \\
\hline NM_008913 & $\begin{array}{l}\text { Protein phosphatase } 3, \\
\text { catalytic subunit, alpha } \\
\text { isoform }\end{array}$ & Ppp3ca & $\begin{array}{c}1.00 \\
\pm \\
0.23 \\
\end{array}$ & $\begin{array}{c}-1.45 \\
\pm \\
0.25 \\
\end{array}$ & $\begin{array}{c}-1.93 \\
\pm \\
0.09 \\
\end{array}$ & $\begin{array}{c}1.41 \\
\pm \\
0.25 \\
\end{array}$ & $\begin{array}{c}-1.74 \\
\pm \\
0.10 \\
\end{array}$ & $\begin{array}{c}-2.12 \\
\pm \\
0.10 \\
\end{array}$ & $\begin{array}{c}-1.00 \\
\pm \\
0.23 \\
\end{array}$ & $\begin{array}{c}-2.14 \\
\pm \\
0.09 \\
\end{array}$ & $\begin{array}{c}-1.82 \\
\pm \\
0.21 \\
\end{array}$ & $\begin{array}{c}1.03 \\
\pm \\
0.20 \\
\end{array}$ & $\begin{array}{c}-1.71 \\
\pm \\
0.11 \\
\end{array}$ & $\begin{array}{c}-1.48 \\
\pm \\
0.12 \\
\end{array}$ \\
\hline NM_023396 & $\begin{array}{l}\text { Reprimo, TP53 dependent } \\
\text { G2 arrest mediator candidate }\end{array}$ & Rprm & $\begin{array}{c}-1.30 \\
\pm \\
0.15\end{array}$ & $\begin{array}{c}-1.44 \\
\pm \\
0.16\end{array}$ & $\begin{array}{c}-1.52 \\
\pm \\
0.13\end{array}$ & $\begin{array}{c}-1.40 \\
\pm \\
0.17\end{array}$ & $\begin{array}{c}-1.80 \\
\pm \\
0.12\end{array}$ & $\begin{array}{c}-1.80 \\
\pm \\
0.11\end{array}$ & $\begin{array}{c}-1.15 \\
\pm \\
0.18\end{array}$ & $\begin{array}{c}-1.80 \\
\pm \\
0.10\end{array}$ & $\begin{array}{c}-1.60 \\
\pm \\
0.10\end{array}$ & $\begin{array}{c}1.00 \\
\pm \\
0.18\end{array}$ & $\begin{array}{c}-2.00 \\
\pm \\
0.09\end{array}$ & $\begin{array}{c}-1.90 \\
\pm \\
0.11\end{array}$ \\
\hline
\end{tabular}


Table 2. Genes encoding for proteins involved in mitotic cell division in individual excitotoxicity global transcriptomic profiles. Genes were selected on the basis of demonstrating at least \pm 1.5 fold-change expression in at least one out of three time-points (5h, 15h and 24h) and passed statistical testing of one-way ANOVA, $\mathrm{p}$ $<0.05$ and FDR correction. The genes were classified in the table according to the first time-point where significant regulation above or below 1.5 is detected.

\begin{tabular}{|c|c|c|c|c|}
\hline & $300 \mu \mathrm{M}$ АMPA & $200 \mu M$ NMDA & $100 \mu \mathrm{M} \mathrm{KA}$ & $250 \mu \mathrm{M}$ Glu \\
\hline $\begin{array}{c}\begin{array}{c}\text { Up-regulation } \\
(5 h)\end{array} \\
\text { Continue ... }\end{array}$ & 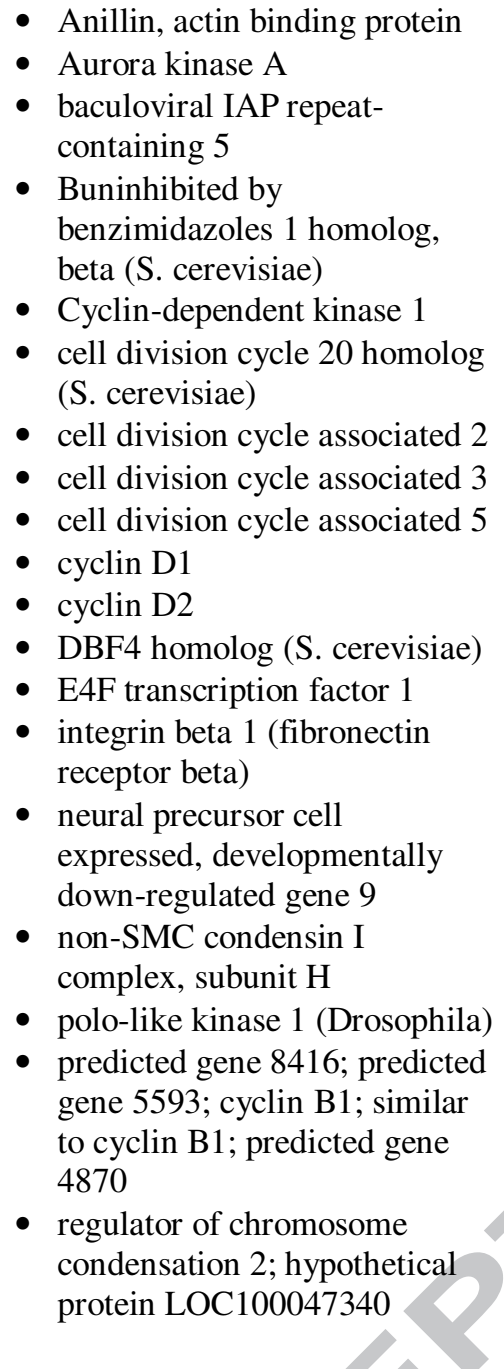 & 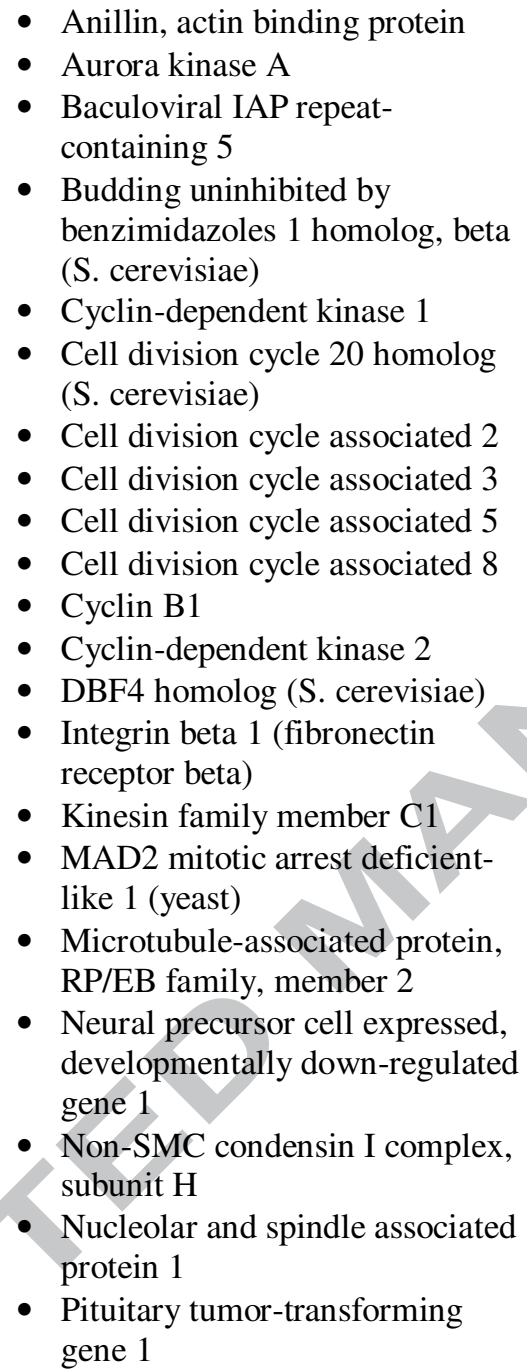 & 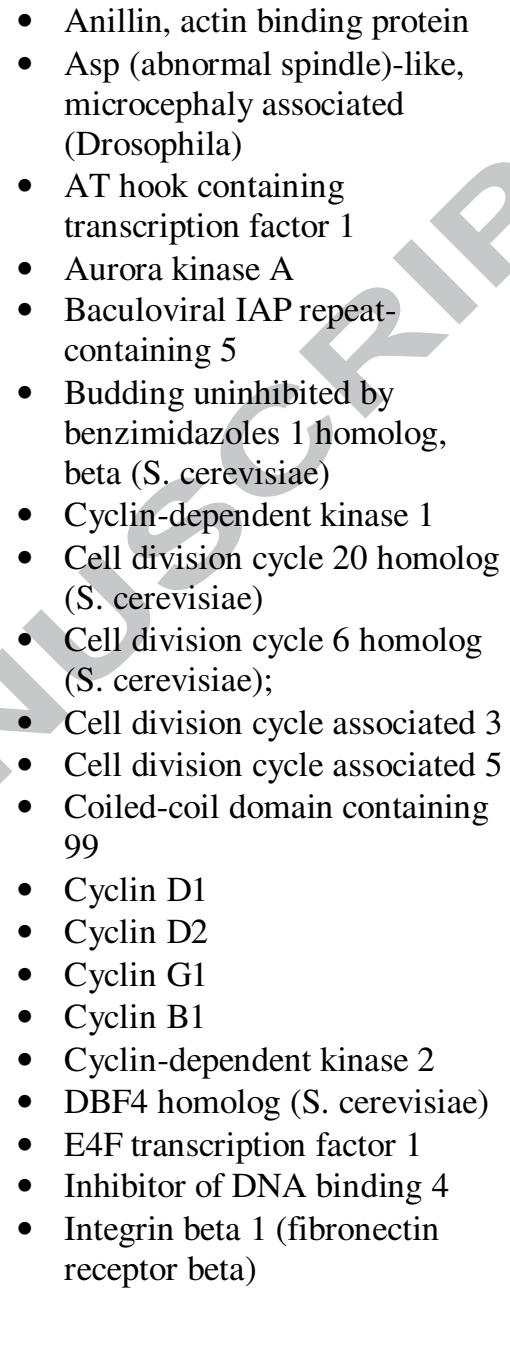 & $\begin{array}{l}\text { - } \text { Anillin, actin binding protein } \\
\text { - } \text { Aurora kinase A } \\
\text { - } \text { Containing } 5 \\
\text { - Cyclin B1 } \\
\text { - Cyclin-dependent kinase } 1 \\
\text { - Cell division cycle associated } 2 \\
\text { - Cell division cycle associated } 3 \\
\text { - Cell division cycle associated } 5 \\
\text { - E4F transcription factor } 1 \\
\text { - Nucleolar and spindle associated } \\
\text { - } \text { Protein } 1 \\
\text { - Pelo-like kinase } 1 \text { (Drosophila) } \\
\text { containing BRCT domain } \\
\text { (zebrafish) } \\
\text { - SPC24, NDC80 kinetochore } \\
\text { complex component, homolog } \\
\text { (S. cerevisiae) } \\
\text { - SPC25, NDC80 kinetochore } \\
\text { complex component, homolog } \\
\text { (S. cerevisiae) } \\
\text { - Sperm associated antigen } 5\end{array}$ \\
\hline
\end{tabular}




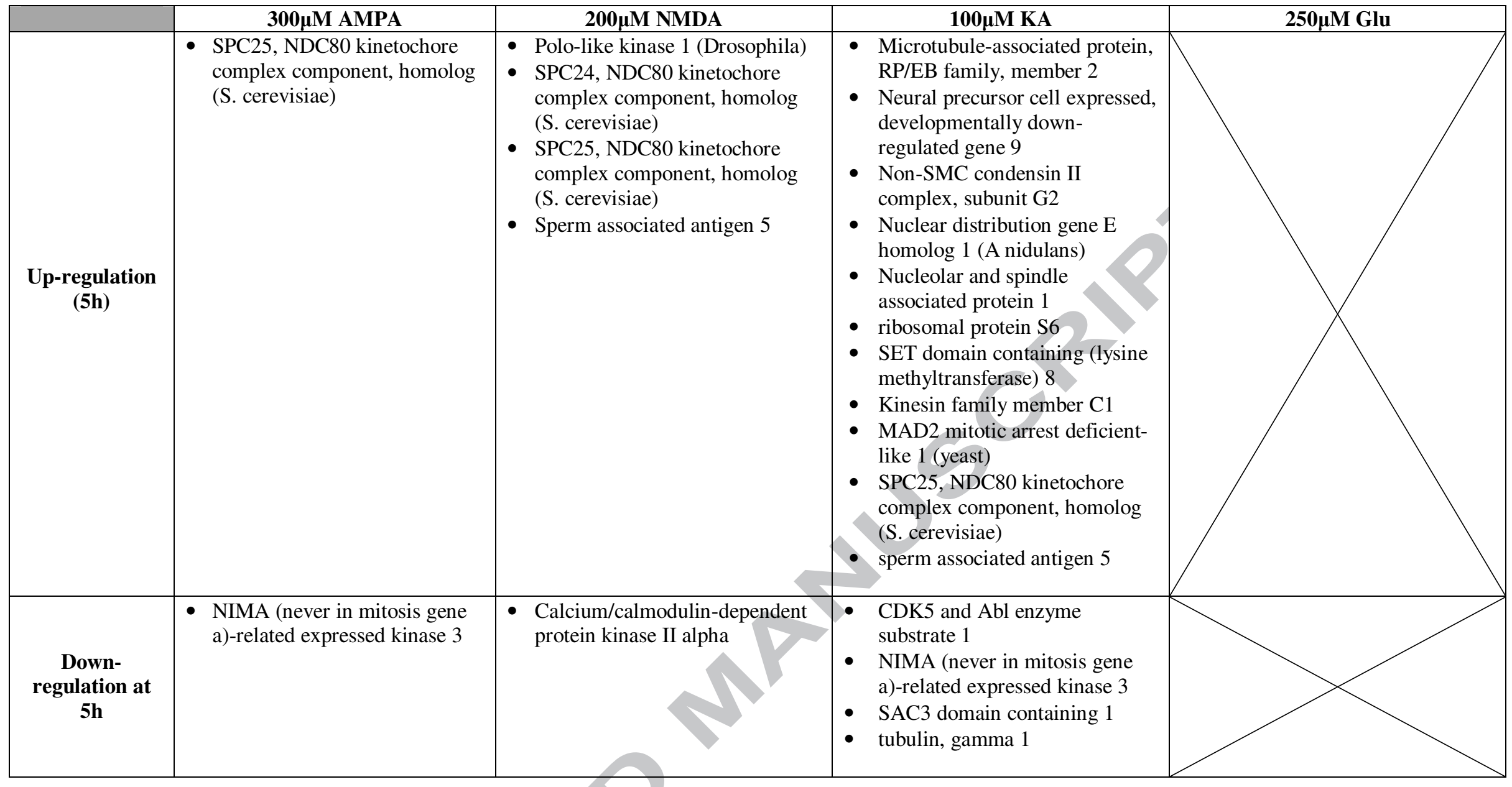




\begin{tabular}{|c|c|c|c|c|}
\hline & 300 $\mu$ M AMPA & $200 \mu \mathrm{M}$ NMDA & $100 \mu \mathrm{M} \mathrm{KA}$ & $250 \mu \mathrm{M}$ Glu \\
\hline $\begin{array}{c}\text { Up-regulation } \\
\text { at } 15 \mathrm{~h}\end{array}$ & 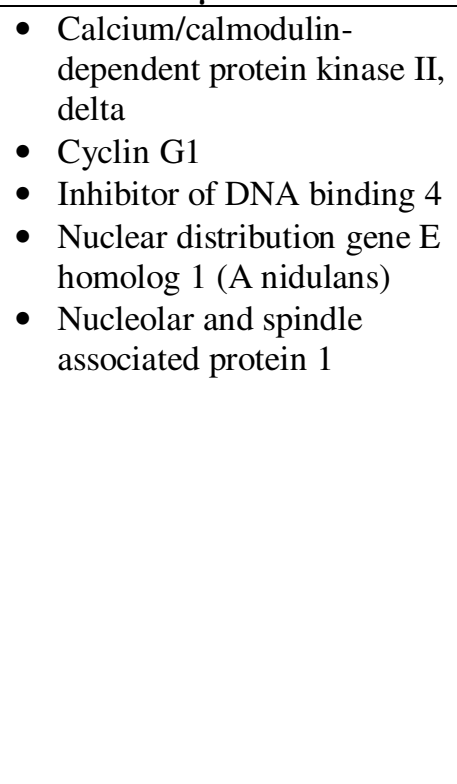 & $\begin{array}{ll}\text { - } & \text { Cyclin G1 } \\
\text { - } & \text { E2F transcription factor } 6 \\
\text { - } & \text { Inhibitor of DNA binding } 4 \\
\text { - } & \text { MAD2 mitotic arrest deficient- } \\
& \text { like } 2 \text { (yeast) } \\
\text { - } & \text { Nuclear distribution gene E } \\
& \text { homolog } 1 \text { (A nidulans) }\end{array}$ & $\begin{array}{l}\text { Anaphase promoting complex } \\
\text { subunit } 1 \\
\text { Neural precursor cell expressed, } \\
\text { developmentally down- } \\
\text { regulated gene } 1\end{array}$ & $\begin{array}{l}\text { - } \text { Cell division cycle } 20 \text { homolog } \\
\text { (S. cerevisiae) } \\
\text { - } \text { Cyclin G1 } \\
\text { - } \text { E2F transcription factor } 6 \\
\text { - Inhibitor of DNA binding } 4 \\
\text { - Integrin beta } 1 \text { (fibronectin } \\
\text { receptor beta) } \\
\text { - Neural precursor cell expressed, } \\
\text { developmentally down-regulated } \\
\text { gene } 1 \\
\text { - Non-SMC condensin I complex, } \\
\text { subunit H } \\
\text { - Nuclear distribution gene E } \\
\text { homolog } 1 \text { (A nidulans) } \\
\text { - Nuclear factor of activated T- } \\
\text { cells, cytoplasmic, calcineurin- } \\
\text { dependent } 1 \\
\text { - Pituitary tumor-transforming } \\
\text { gene } 1\end{array}$ \\
\hline $\begin{array}{c}\text { Down- } \\
\text { regulation at } \\
15 \mathrm{~h}\end{array}$ & $\begin{array}{l}\text { - } \text { Calcium/calmodulin- } \\
\text { dependent protein kinase II, } \\
\text { beta } \\
\text { - } \text { Tubulin, beta } 3\end{array}$ & $\begin{array}{l}\text { - } \text { Calcium/calmodulin-dependent } \\
\text { protein kinase II, beta } \\
\text { - Cyclin D1 } \\
\text { - Fibronectin type } 3 \text { and SPRY } \\
\text { domain-containing protein } \\
\text { - Protein phosphatase 3, catalytic } \\
\text { subunit, alpha isoform } \\
\text { - Ras homolog gene family, } \\
\text { - } \text { member U } \\
\text { - Ttathmin } 1 \\
\text { Tubulin, beta } 3\end{array}$ & 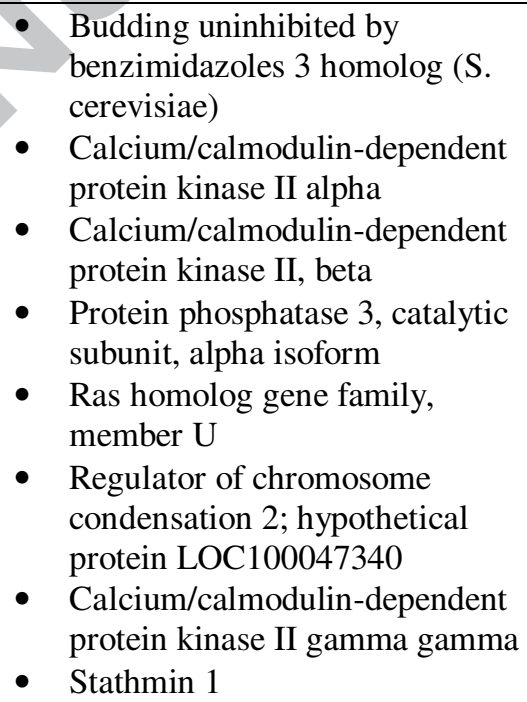 & $\begin{array}{l}\text { - } \text { Amyloid beta (A4) precursor } \\
\text { protein } \\
\text { - } \text { Calcium/calmodulin-dependent } \\
\text { protein kinase II alpha } \\
\text { - } \text { Calcium/calmodulin-dependent } \\
\text { protein kinase II, beta } \\
\text { - Microtubule-associated protein, } \\
\text { RP/EB family, member } 2 \\
\text { - Polo-like kinase } 2 \text { (Drosophila) } \\
\text { - Protein phosphatase 3, catalytic } \\
\text { - } \text { subunit, alpha isoform } \\
\text { Ras homolog gene family, } \\
\text { member U }\end{array}$ \\
\hline
\end{tabular}




\begin{tabular}{|c|c|c|c|c|}
\hline & 300 $\mu$ M AMPA & $200 \mu M$ NMDA & $100 \mu \mathrm{M}$ KA & $250 \mu \mathrm{M}$ Glu \\
\hline $\begin{array}{c}\text { Down- } \\
\text { regulation at } \\
24 \mathrm{~h}\end{array}$ & $\begin{array}{l}\text { - Centrin } 2 \\
\text { - Protein phosphatase 3, } \\
\text { catalytic subunit, alpha } \\
\text { isoform }\end{array}$ & - Tubulin, gamma 1 & $\begin{array}{ll}\text { - } & \text { ADP-ribosylation factor-like } \\
& 8 \mathrm{~A} \\
\text { - } & \text { Activating transcription factor } 6 \\
& \text { beta } \\
\text { - } & \text { Centrin } 2 \\
\text { - } & \text { Centrin } 3 \\
\text { - } & \text { Checkpoint with forkhead and } \\
\text { - } & \text { Chng finger domains } \\
\text { - } & \text { 1A; predicted gene } 8515 \\
\text { - } & \text { Thioredoxin-like 4B } \\
\text { - } & \text { Tubulin, beta } 3\end{array}$ & \\
\hline
\end{tabular}


Table 3. Validation of microarray data using real-time PCR technique on mouse culture treated with $250 \mu \mathrm{M}$ Glu. All fold-change expressions are statistically significant at $p<0.05$. Data are expressed as mean \pm sem.

\begin{tabular}{|c|c|c|c|c|c|c|c|c|}
\hline \multirow[b]{2}{*}{ GenBank } & \multirow[b]{2}{*}{ Gene Title } & \multirow[b]{2}{*}{ Symbol } & \multicolumn{2}{|c|}{ 5h } & \multicolumn{2}{|c|}{ 15h } & \multicolumn{2}{|c|}{$24 \mathrm{~h}$} \\
\hline & & & Microarray & $\begin{array}{c}\text { Real-time } \\
\text { PCR }\end{array}$ & Microarray & $\begin{array}{c}\text { Real-time } \\
\text { PCR }\end{array}$ & Microarray & $\begin{array}{c}\text { Real-time } \\
\text { PCR }\end{array}$ \\
\hline NM_030704 & $\begin{array}{l}\text { Heat shock } \\
\text { protein } 8\end{array}$ & Hspb8 & $1.29 \pm 0.31$ & $1.42 \pm 0.69$ & $4.40 \pm 1.06$ & $9.29 \pm 0.55$ & $2.63 \pm 0.70$ & \pm 0.72 \\
\hline NM_010442 & $\begin{array}{l}\text { Heme } \\
\text { oxygenase } 1\end{array}$ & Hmox 1 & $1.59 \pm 0.34$ & & $2.37 \pm 0.41$ & $1.78 \pm 0.62$ & $1.51 \pm 0.38$ & \\
\hline NM_029688 & $\begin{array}{l}\text { Sulfiredoxin } 1 \\
\text { homolog }\end{array}$ & Srxn1 & $-1.20 \pm 0.29$ & & $2.16 \pm 0.73$ & $2.99 \pm 0.55$ & $1.17 \pm 0.43$ & \\
\hline NM_011121 & $\begin{array}{l}\text { Polo-like kinase } \\
1\end{array}$ & Plk1 & $2.08 \pm 0.32$ & & $2.06 \pm 0.37$ & $1.64 \pm 0.59$ & $1.62 \pm 0.30$ & \\
\hline NM_007585 & Annexin A2 & AnxA2 & $1.52 \pm 0.25$ & & $1.93 \pm 0.31$ & & $2.05 \pm 0.43$ & $8.25 \pm 0.61$ \\
\hline NM_020581 & $\begin{array}{l}\text { Angiopoietin- } \\
\text { like } 4\end{array}$ & Angpt14 & $2.00 \pm 0.46$ & $3.28 \pm 0.66$ & $8.27 \pm 1.62$ & & $8.24 \pm 1.58$ & $5.63 \pm 0.58$ \\
\hline NM_011497 & Aurora kinase $\mathrm{A}$ & Aurka & $1.91 \pm 0.42$ & $3.31 \pm 0.69$ & $1.98 \pm 0.50$ & $1.95 \pm 0.72$ & $1.59 \pm 0.44$ & $2.97 \pm 1.11$ \\
\hline NM_028109 & $\begin{array}{l}\text { TPX2, } \\
\text { microtubule- } \\
\text { associated } \\
\text { protein homolog }\end{array}$ & Tpx2 & $1.70 \pm 0.42$ & & $2.09 \pm 0.55$ & $4.79 \pm 0.78$ & $1.57 \pm 0.46$ & $4.21 \pm 0.60$ \\
\hline
\end{tabular}




\section{Supplementary data}

Supplementary table 1. Significantly expressed genes (with fold-change of at least \pm 1.5 in a minimum one out of three time-points and passed One-way ANOVA, $p<0.05$ ) encoding for proteins involved in mitotic cell cycle upon $300 \mu \mathrm{M}$ AMPA-mediated excitotoxicity in cultured primary cortical neurons. Data are expressed as mean \pm sem.

\begin{tabular}{|c|c|c|c|c|c|}
\hline & & & & 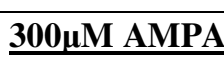 & \\
\hline Genbank & Title & Symbol & $5 \mathrm{~h}$ & $15 \mathrm{~h}$ & $24 \mathrm{~h}$ \\
\hline Mitotic cell cy & & & & & $\gamma$ \\
\hline NM_172301 & Cyclin B1 & Ccnb1 & $2.75 \pm 0.63$ & $1.66 \pm 0.40$ & $1.03 \pm 0.30$ \\
\hline NM_007659 & Cyclin-dependent kinase 1 & Cdk1 & $2.58 \pm 0.62$ & $1.54 \pm 0.45$ & $-1.10 \pm 0.26$ \\
\hline NM_011121 & $\begin{array}{l}\text { Polo-like kinase } 1 \\
\text { (Drosophila) }\end{array}$ & Plk1 & $2.40 \pm 0.52$ & $1.19 \pm 0.42$ & $-1.08 \pm 0.20$ \\
\hline NM_013726 & $\begin{array}{l}\text { DBF4 homolog (S. } \\
\text { cerevisiae) }\end{array}$ & Dbf4 & $2.32 \pm 0.55$ & $1.76 \pm 0.45$ & $1.25 \pm 0.35$ \\
\hline NM_011497 & Aurora kinase A & AurkA & $2.31 \pm 0.56$ & $1.48 \pm 0.36$ & $1.04 \pm 0.25$ \\
\hline NM_009829 & Cyclin D2 & Ccnd2 & $2.22 \pm 0.61$ & $1.50 \pm 0.33$ & $1.01 \pm 0.18$ \\
\hline NM_013538 & $\begin{array}{l}\text { Cell division cycle } \\
\text { associated } 3\end{array}$ & Cdca3 & $2.17 \pm 0.65$ & $1.45 \pm 0.45$ & $1.01 \pm 0.28$ \\
\hline NM_009773 & $\begin{array}{l}\text { Budding uninhibited by } \\
\text { benzimidazoles } 1 \\
\text { homolog, beta ( } \mathrm{S} \text {. } \\
\text { cerevisiae) }\end{array}$ & Bublb & $2.15 \pm 0.62$ & $1.34 \pm 0.54$ & $-1.09 \pm 0.26$ \\
\hline NM_028390 & $\begin{array}{l}\text { Anillin, actin binding } \\
\text { protein }\end{array}$ & Anln & $1.97 \pm 0.51$ & $1.28 \pm 0.28$ & $-1.10 \pm 0.19$ \\
\hline NM_009689 & $\begin{array}{l}\text { Baculoviral IAP repeat- } \\
\text { containing } 5\end{array}$ & Birc5 & $1.94 \pm 0.50$ & $1.25 \pm 0.37$ & $-1.03 \pm 0.26$ \\
\hline NM_175384 & $\begin{array}{l}\text { Cell division cycle } \\
\text { associated } 2\end{array}$ & Cdca2 & $1.92 \pm 0.42$ & $1.12 \pm 0.29$ & $-1.12 \pm 0.19$ \\
\hline NM_173867 & $\begin{array}{l}\text { Regulator of chromosome } \\
\text { condensation } 2\end{array}$ & Rcc2 & $1.90 \pm 0.59$ & $1.92 \pm 0.55$ & $1.64 \pm 0.47$ \\
\hline NM_026410 & $\begin{array}{l}\text { Cell division cycle } \\
\text { associated } 5\end{array}$ & Cdca5 & $1.86 \pm 0.38$ & $1.10 \pm 0.32$ & $-1.21 \pm 0.22$ \\
\hline NM_144818 & $\begin{array}{l}\text { Non-SMC condensin I } \\
\text { complex, subunit } \mathrm{H}\end{array}$ & Ncaph & $1.83 \pm 0.69$ & $1.32 \pm 0.63$ & $1.02 \pm 0.46$ \\
\hline NM_025565 & $\begin{array}{l}\text { SPC25, NDC80 } \\
\text { kinetochore complex } \\
\text { component, homolog (S. } \\
\text { cerevisiae) }\end{array}$ & Spc25 & $1.79 \pm 0.52$ & $1.50 \pm 0.52$ & $-1.08 \pm 0.32$ \\
\hline NM_017464 & $\begin{array}{l}\text { Neural precursor cell } \\
\text { expressed, } \\
\text { developmentally down- } \\
\text { regulated gene } 9\end{array}$ & Nedd9 & $1.72 \pm 0.47$ & $1.97 \pm 0.56$ & $1.31 \pm 0.36$ \\
\hline NM_023223 & $\begin{array}{l}\text { Cell division cycle } 20 \\
\text { homolog (S. cerevisiae) }\end{array}$ & $\mathrm{Cdc} 20$ & $1.65 \pm 0.52$ & $1.14 \pm 0.34$ & $1.03 \pm 0.33$ \\
\hline NM_010578 & $\begin{array}{l}\text { Integrin beta } 1 \\
\text { (fibronectin receptor beta) }\end{array}$ & Itgb1 & $1.58 \pm 0.33$ & $1.29 \pm 0.23$ & $1.13 \pm 0.22$ \\
\hline NM_007893 & E4F transcription factor 1 & E4f1 & $1.53 \pm 0.45$ & $1.42 \pm 0.41$ & $1.28 \pm 0.38$ \\
\hline NM_007631 & Cyclin D1 & Ccnd1 & $1.46 \pm 0.45$ & $-1.00 \pm 0.25$ & $-1.63 \pm 0.18$ \\
\hline
\end{tabular}




\begin{tabular}{|c|c|c|c|c|c|}
\hline NM_023317 & $\begin{array}{l}\text { Nuclear distribution gene } \\
\text { E homolog } 1 \text { (A nidulans) }\end{array}$ & Nde1 & $1.40 \pm 0.39$ & $1.74 \pm 0.45$ & $1.11 \pm 0.27$ \\
\hline NM_009831 & Cyclin G1 & Ccng1 & $1.28 \pm 0.32$ & $1.58 \pm 0.49$ & $1.05 \pm 0.23$ \\
\hline NM_023813 & $\begin{array}{l}\text { Calcium/calmodulin- } \\
\text { dependent protein kinase } \\
\text { II, delta }\end{array}$ & Camk2d & $1.28 \pm 0.38$ & $1.57 \pm 0.41$ & $1.24 \pm 0.29$ \\
\hline NM_031166 & $\begin{array}{l}\text { Inhibitor of DNA binding } \\
4\end{array}$ & Id 4 & $1.27 \pm 0.38$ & $1.65 \pm 0.48$ & $1.07 \pm 0.28$ \\
\hline NM_008913 & $\begin{array}{l}\text { Protein phosphatase } 3 \text {, } \\
\text { catalytic subunit, alpha } \\
\text { isoform }\end{array}$ & Ppp3ca & $1.01 \pm 0.23$ & $-1.45 \pm 0.25$ & $-1.93 \pm 0.09$ \\
\hline NM_007595 & $\begin{array}{l}\text { Calcium/calmodulin- } \\
\text { dependent protein kinase } \\
\text { II, beta }\end{array}$ & Camk2b & $-1.04 \pm 0.16$ & $-1.56 \pm 0.13$ & $-1.52 \pm 0.11$ \\
\hline NM_019405 & Centrin 2 & Cetn2 & $-1.07 \pm 0.24$ & $-1.33 \pm 0.24$ & $-1.83 \pm 0.21$ \\
\hline NM_023279 & Tubulin, beta 3 class III & Tubb3 & $-1.39 \pm 0.23$ & $-1.82 \pm 0.18$ & $-1.75 \pm 0.19$ \\
\hline NM_011848 & $\begin{array}{l}\text { NIMA (never in mitosis } \\
\text { gene a)-related expressed } \\
\text { kinase } 3\end{array}$ & Nek3 & $-1.78 \pm 0.13$ & $-1.12 \pm 0.16$ & $-1.30 \pm 0.13$ \\
\hline
\end{tabular}


Supplementary table 2. Significantly expressed genes (with fold-change of at least \pm 1.5 in a minimum one out of three time-points and passed One-way ANOVA, $p<0.05)$ encoding for proteins involved in mitotic cell cycle upon $100 \mu \mathrm{M}$ KA-mediated excitotoxicity in cultured primary cortical neurons. Data are expressed as mean \pm sem.

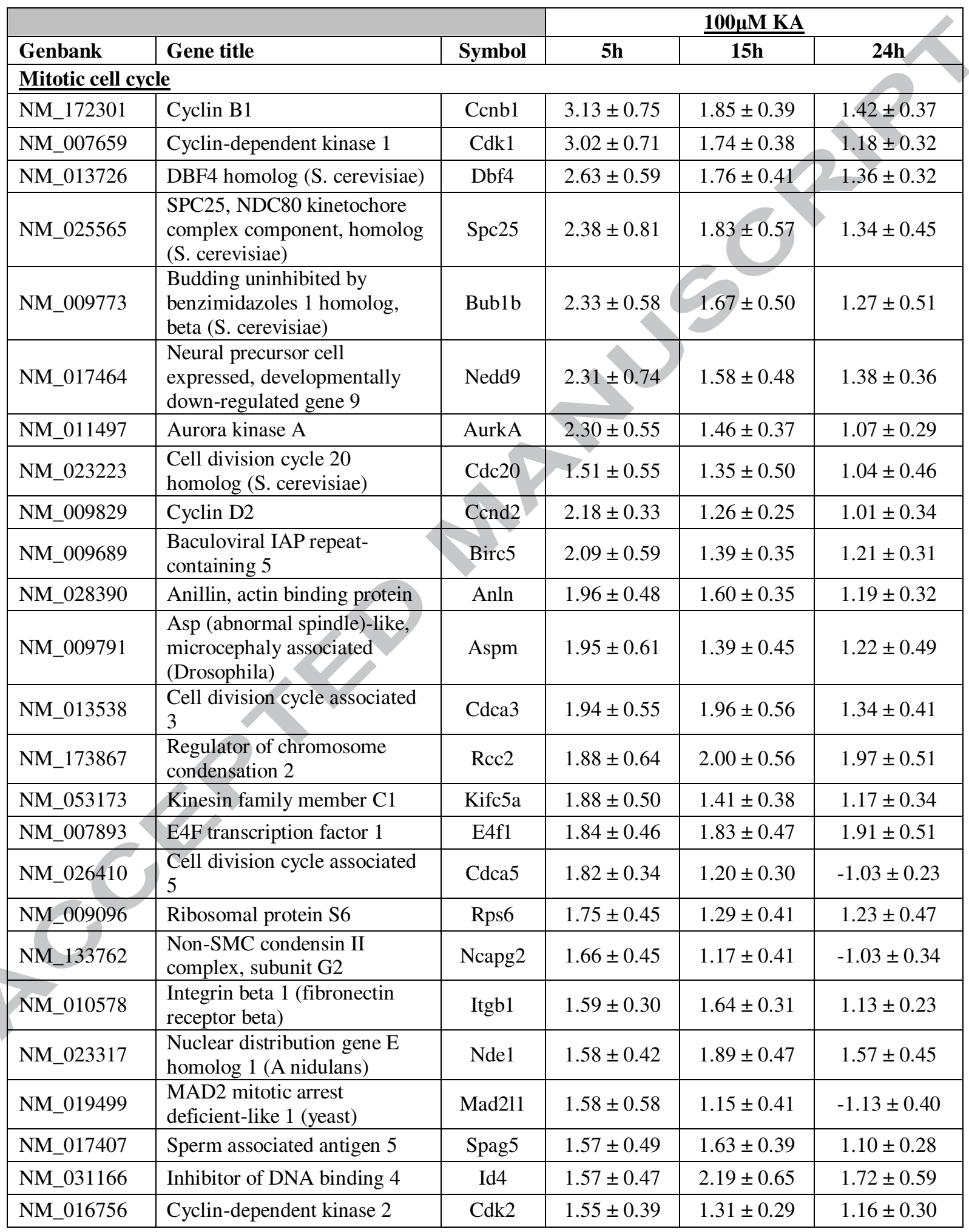




\begin{tabular}{|c|c|c|c|c|c|}
\hline NM_026375 & $\begin{array}{l}\text { AT hook containing } \\
\text { transcription factor } 1\end{array}$ & Ahctf1 & $1.55 \pm 0.38$ & $1.27 \pm 0.29$ & $1.07 \pm 0.29$ \\
\hline NM_027411 & $\begin{array}{l}\text { Coiled-coil domain containing } \\
99\end{array}$ & Ccdc99 & $1.54 \pm 0.52$ & $1.10 \pm 0.29$ & $1.07 \pm 0.38$ \\
\hline NM_011799 & $\begin{array}{l}\text { Cell division cycle } 6 \text { homolog } \\
\text { (S. cerevisiae) }\end{array}$ & Cdc6 & $1.53 \pm 0.42$ & $1.06 \pm 0.27$ & $1.10 \pm 0.34$ \\
\hline NM_009831 & Cyclin G1 & Ccng1 & $1.53 \pm 0.33$ & $1.35 \pm 0.25$ & $-1.01 \pm 0.22$ \\
\hline NM_007631 & Cyclin D1 & Ccnd1 & $1.51 \pm 0.42$ & $1.06 \pm 0.31$ & $-1.28 \pm 0.24$ \\
\hline NM_030241 & $\begin{array}{l}\text { SET domain containing } \\
\text { (lysine methyltransferase) } 8\end{array}$ & Setd 8 & $1.51 \pm 0.43$ & $-1.07 \pm 0.25$ & $-1.14 \pm 0.24$ \\
\hline NM_153058 & $\begin{array}{l}\text { Microtubule-associated } \\
\text { protein, RP/EB family, } \\
\text { member } 2\end{array}$ & Mapre2 & $1.50 \pm 0.49$ & $1.44 \pm 0.42$ & $1.08 \pm 0.39$ \\
\hline NM_008682 & $\begin{array}{l}\text { Neural precursor cell } \\
\text { expressed, developmentally } \\
\text { down-regulated gene } 1\end{array}$ & Nedd1 & $1.43 \pm 0.33$ & $1.67 \pm 0.33$ & $1.23 \pm 0.34$ \\
\hline NM_008913 & $\begin{array}{l}\text { Protein phosphatase } 3, \\
\text { catalytic subunit, alpha } \\
\text { isoform }\end{array}$ & Ppp3ca & $1.41 \pm 0.25$ & $-1.74 \pm 0.10$ & $-2.12 \pm 0.10$ \\
\hline NM_019641 & Stathmin 1 & Stmn 1 & $1.40 \pm 0.39$ & $-2.29 \pm 0.13$ & $-1.60 \pm 0.27$ \\
\hline NM_019405 & Centrin 2 & Cetn2 & $1.36 \pm 0.39$ & $-1.41 \pm 0.23$ & $-1.91 \pm 0.17$ \\
\hline NM_009774 & $\begin{array}{l}\text { Budding uninhibited by } \\
\text { benzimidazoles } 3 \text { homolog ( } \mathrm{S} \text {. } \\
\text { cerevisiae) }\end{array}$ & Bub3 & $1.17 \pm 0.31$ & $-1.59 \pm 0.14$ & $-1.66 \pm 0.16$ \\
\hline NM_007684 & Centrin 3 & Cetn3 & $1.16 \pm 0.32$ & $-1.25 \pm 0.19$ & $-1.61 \pm 0.19$ \\
\hline NM_008569 & $\begin{array}{l}\text { Anaphase promoting complex } \\
\text { subunit } 1\end{array}$ & Apc1 & $1.16 \pm 0.25$ & $1.61 \pm 0.39$ & $1.31 \pm 0.35$ \\
\hline NM_026823 & $\begin{array}{l}\text { ADP-ribosylation factor-like } \\
8 \mathrm{~A}\end{array}$ & Arl8a & $1.15 \pm 0.23$ & $-1.37 \pm 0.18$ & $-1.78 \pm 0.14$ \\
\hline NM_145606 & $\begin{array}{l}\text { Chromatin modifying protein } \\
\text { 1A }\end{array}$ & Chmpla & $1.11 \pm 0.26$ & $-1.43 \pm 0.13$ & $-1.59 \pm 0.12$ \\
\hline NM_178597 & $\begin{array}{l}\text { Calcium/calmodulin- } \\
\text { dependent protein kinase type } \\
\text { II gamma chain }\end{array}$ & Camkg & $1.10 \pm 0.24$ & $-1.69 \pm 0.12$ & $-1.71 \pm 0.17$ \\
\hline NM_007595 & $\begin{array}{l}\text { Calcium/calmodulin- } \\
\text { dependent protein kinase II, } \\
\text { beta }\end{array}$ & Camk2b & $1.01 \pm 0.16$ & $-2.09 \pm 0.08$ & $-2.25 \pm 0.10$ \\
\hline NM_017406 & $\begin{array}{l}\text { Activating transcription factor } \\
6 \text { beta }\end{array}$ & Atf6b & $-1.01 \pm 0.21$ & $-1.38 \pm 0.14$ & $-1.76 \pm 0.14$ \\
\hline NM_023279 & Tubulin, beta 3 class III & Tubb3 & $-1.13 \pm 0.33$ & $-2.22 \pm 0.15$ & $-2.58 \pm 0.13$ \\
\hline NM_177407 & $\begin{array}{l}\text { Calcium/calmodulin- } \\
\text { dependent protein kinase II } \\
\text { alpha }\end{array}$ & Camk2a & $-1.15 \pm 0.31$ & $-1.62 \pm 0.20$ & $-1.54 \pm 0.20$ \\
\hline NM_172717 & $\begin{array}{l}\text { Checkpoint with forkhead and } \\
\text { ring finger domains }\end{array}$ & Chfr & $-1.16 \pm 0.30$ & $-1.42 \pm 0.25$ & $-1.67 \pm 0.22$ \\
\hline NM_133955 & $\begin{array}{l}\text { Ras homolog gene family, } \\
\text { member U }\end{array}$ & Rhou & $-1.32 \pm 0.16$ & $-1.98 \pm 0.10$ & $-2.18 \pm 0.09$ \\
\hline NM_175646 & Thioredoxin-like 4B & Txnl4b & $-1.41 \pm 0.21$ & $-1.29 \pm 0.20$ & $-1.68 \pm 0.16$ \\
\hline NM_022021 & $\begin{array}{l}\text { CDK5 and Abl enzyme } \\
\text { substrate } 1\end{array}$ & Cables1 & $-1.56 \pm 0.14$ & $-1.87 \pm 0.12$ & $-2.11 \pm 0.12$ \\
\hline NM_133678 & SAC3 domain containing 1 & Sac3d1 & $-1.58 \pm 0.26$ & $-1.55 \pm 0.23$ & $-1.80 \pm 0.17$ \\
\hline NM_134024 & Tubulin, gamma 1 & Tubg & $-1.66 \pm 0.13$ & $-1.52 \pm 0.13$ & $-1.70 \pm 0.15$ \\
\hline
\end{tabular}




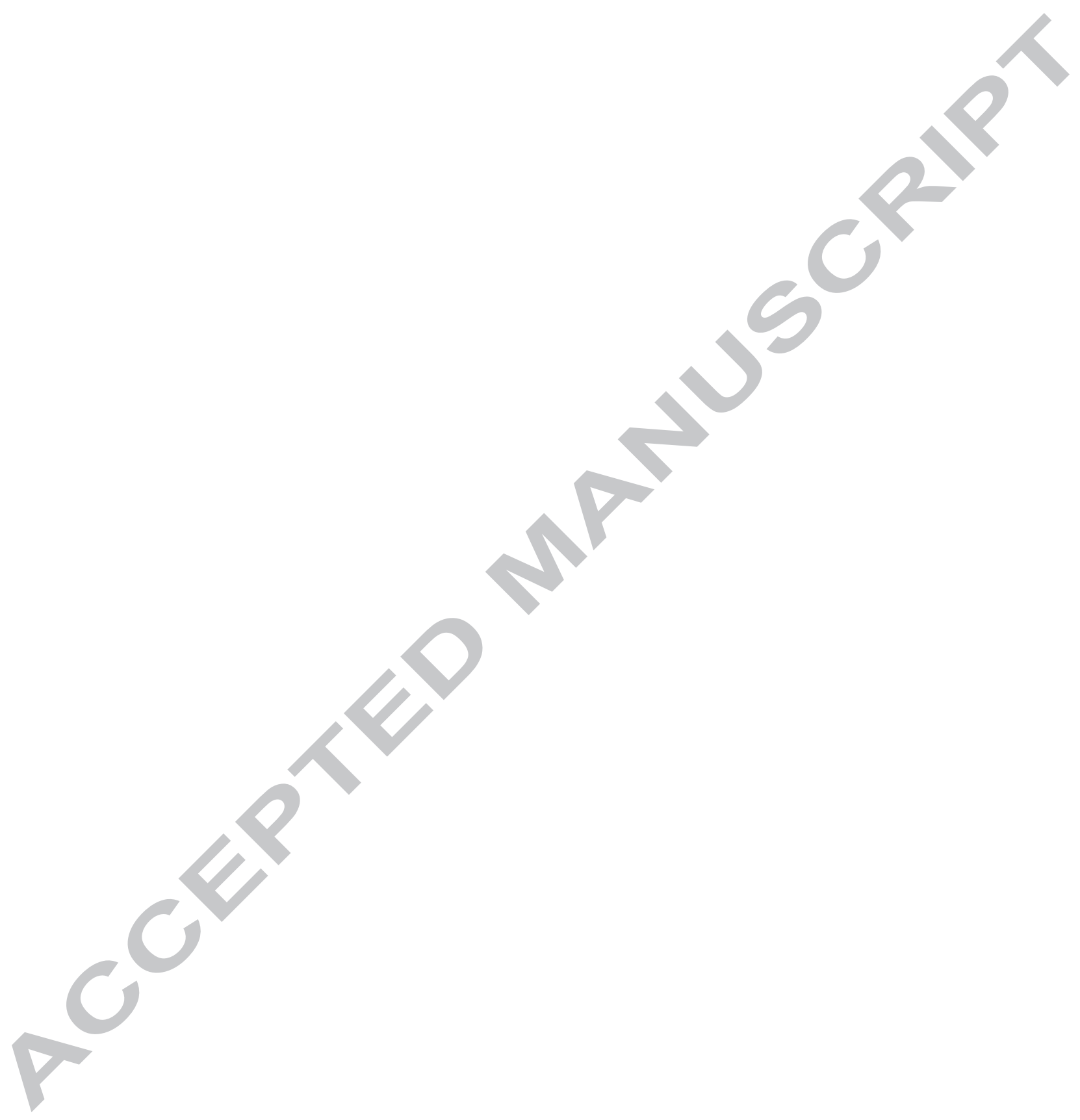


Supplementary table 3. Significantly expressed genes (with fold-change of at least \pm 1.5 in a minimum one out of three time-points and passed One-way ANOVA, $p<0.05$ ) encoding for proteins involved in mitotic cell cycle upon $200 \mu \mathrm{M}$ NMDA-mediated excitotoxicity in cultured primary cortical neurons. Data are expressed as mean \pm sem.

\begin{tabular}{|c|c|c|c|c|c|}
\hline & & & & $00 \mu \mathrm{M} N \mathrm{NMD}$ & \\
\hline Genbank & Genbank & Symbol & $5 \mathbf{h}$ & $15 \mathrm{~h}$ & $24 h$ \\
\hline Mitotic cell c & cle & & & & \\
\hline NM_013538 & $\begin{array}{l}\text { Cell division cycle } \\
\text { associated } 3\end{array}$ & Cdca3 & $2.18 \pm 0.62$ & $1.78 \pm 0.42$ & $1.04 \pm 0.26$ \\
\hline NM_025565 & $\begin{array}{l}\text { SPC25, NDC80 kinetochore } \\
\text { complex component, } \\
\text { homolog (S. cerevisiae) }\end{array}$ & Spc25 & $2.11 \pm 0.48$ & $1.82 \pm 0.49$ & $1.21 \pm 0.32$ \\
\hline NM_007659 & Cyclin-dependent kinase 1 & Cdk1 & $2.10 \pm 0.51$ & $1.66 \pm 0.39$ & $1.20 \pm 0.26$ \\
\hline NM_172301 & Cyclin B1 & Ccnb1 & $2.07 \pm 0.50$ & $1.62 \pm 0.41$ & $1.19 \pm 0.29$ \\
\hline NM_009689 & $\begin{array}{l}\text { Baculoviral IAP repeat- } \\
\text { containing } 5\end{array}$ & Birc5 & $1.96 \pm 0.56$ & $1.41 \pm 0.33$ & $-1.02 \pm 0.22$ \\
\hline NM_011121 & $\begin{array}{l}\text { Polo-like kinase } 1 \\
\text { (Drosophila) }\end{array}$ & Plk1 & $1.90 \pm 0.38$ & $1.44 \pm 0.21$ & $-1.10 \pm 0.20$ \\
\hline NM_019499 & $\begin{array}{l}\text { MAD2 mitotic arrest } \\
\text { deficient-like } 1 \text { (yeast) }\end{array}$ & Mad211 & $1.87 \pm 0.62$ & $1.09 \pm 0.34$ & $-1.12 \pm 0.25$ \\
\hline NM_023223 & $\begin{array}{l}\text { Cell division cycle } 20 \\
\text { homolog }(\mathrm{S} \text {. cerevisiae })\end{array}$ & Cdc20 & $1.87 \pm 0.39$ & $1.43 \pm 0.31$ & $-1.02 \pm 0.24$ \\
\hline NM_026410 & $\begin{array}{l}\text { Cell division cycle } \\
\text { associated } 5\end{array}$ & Cdca5 & $1.85 \pm 0.44$ & $1.26 \pm 0.22$ & $-1.11 \pm 0.20$ \\
\hline NM_144818 & $\begin{array}{l}\text { Non-SMC condensin I } \\
\text { complex, subunit H }\end{array}$ & Ncaph & $1.85 \pm 0.64$ & $1.28 \pm 0.45$ & $1.10 \pm 0.34$ \\
\hline NM_028390 & Anillin, actin binding protein & Anln & $1.84 \pm 0.41$ & $1.50 \pm 0.33$ & $1.18 \pm 0.26$ \\
\hline NM_008682 & $\begin{array}{l}\text { Neural precursor cell } \\
\text { expressed, developmentally } \\
\text { down-regulated gene } 1\end{array}$ & Nedd1 & $1.71 \pm 0.42$ & $1.85 \pm 0.40$ & $1.36 \pm 0.27$ \\
\hline NM_011497 & Aurora kinase $\mathrm{A}$ & AurkA & $1.65 \pm 0.40$ & $1.31 \pm 0.32$ & $1.11 \pm 0.26$ \\
\hline NM_016756 & Cyclin-dependent kinase 2 & $\mathrm{Cdk} 2$ & $1.60 \pm 0.28$ & $1.48 \pm 0.26$ & $1.33 \pm 0.29$ \\
\hline NM_009773 & $\begin{array}{l}\text { Budding uninhibited by } \\
\text { benzimidazoles } 1 \text { homolog, } \\
\text { beta (S. cerevisiae) }\end{array}$ & Bub1b & $1.60 \pm 0.41$ & $1.28 \pm 0.39$ & $-1.06 \pm 0.26$ \\
\hline NM_053173 & Kinesin family member C1 & Kifc5a & $1.59 \pm 0.44$ & $1.19 \pm 0.26$ & $1.01 \pm 0.21$ \\
\hline NM_026560 & $\begin{array}{l}\text { Cell division cycle } \\
\text { associated } 8\end{array}$ & Cdca 8 & $1.58 \pm 0.48$ & $1.22 \pm 0.32$ & $1.01 \pm 0.27$ \\
\hline NM_175384 & $\begin{array}{l}\text { Cell division cycle } \\
\text { associated } 2\end{array}$ & Cdca 2 & $1.57 \pm 0.30$ & $1.32 \pm 0.25$ & $-1.01 \pm 0.20$ \\
\hline NM_013917 & $\begin{array}{l}\text { Pituitary tumor-transforming } \\
\text { gene } 1\end{array}$ & Pttg1 & $1.57 \pm 0.62$ & $1.09 \pm 0.29$ & $-1.23 \pm 0.21$ \\
\hline NM_026282 & $\begin{array}{l}\text { SPC24, NDC80 kinetochore } \\
\text { complex component, } \\
\text { homolog (S. cerevisiae) }\end{array}$ & Spc24 & $1.55 \pm 0.50$ & $1.29 \pm 0.37$ & $-1.06 \pm 0.25$ \\
\hline NM_017407 & Sperm associated antigen 5 & Spag5 & $1.54 \pm 0.37$ & $1.43 \pm 0.32$ & $1.02 \pm 0.22$ \\
\hline NM_010578 & $\begin{array}{l}\text { Integrin beta } 1 \text { (fibronectin } \\
\text { receptor beta) }\end{array}$ & Itgb1 & $1.54 \pm 0.31$ & $1.45 \pm 0.29$ & $1.10 \pm 0.20$ \\
\hline NM_013726 & $\begin{array}{l}\text { DBF4 homolog }(\mathrm{S} . \\
\text { cerevisiae) }\end{array}$ & Dbf4 & $1.51 \pm 0.40$ & $1.11 \pm 0.23$ & $1.28 \pm 0.35$ \\
\hline NM_033270 & E2F transcription factor 6 & E2f6 & $1.41 \pm 0.32$ & $1.50 \pm 0.24$ & $1.15 \pm 0.23$ \\
\hline
\end{tabular}




\section{ACCEPTED MANUSCRIPT}

\begin{tabular}{|l|l|c|c|c|c|}
\hline NM_031166 & Inhibitor of DNA binding 4 & Id4 & $1.36 \pm 0.41$ & $1.89 \pm 0.53$ & $1.15 \pm 0.34$ \\
\hline NM_027985 & $\begin{array}{l}\text { MAD2 mitotic arrest } \\
\text { deficient-like 2 (yeast) }\end{array}$ & Mad212 & $1.33 \pm 0.29$ & $1.50 \pm 0.37$ & $1.05 \pm 0.27$ \\
\hline NM_009831 & Cyclin G1 & Ccng1 & $1.30 \pm 0.34$ & $1.55 \pm 0.33$ & $1.25 \pm 0.34$ \\
\hline NM_023317 & $\begin{array}{l}\text { Nuclear distribution gene E } \\
\text { homolog 1 (A nidulans) }\end{array}$ & Nde1 & $1.28 \pm 0.32$ & $1.56 \pm 0.35$ & $1.24 \pm 0.30$ \\
\hline NM_019641 & Stathmin 1 & Stmn1 & $1.19 \pm 0.39$ & $-1.80 \pm 0.16$ & $-1.34 \pm 0.22$ \\
\hline NM_023279 & Tubulin, beta 3 class III & Tubb3 & $1.02 \pm 0.31$ & $-1.77 \pm 0.17$ & $-1.66 \pm 0.17$ \\
\hline NM_007631 & Cyclin D1 & Ccnd1 & $1.02 \pm 0.31$ & $-1.61 \pm 0.15$ & $-1.65 \pm 0.15$ \\
\hline NM_008913 & $\begin{array}{l}\text { Potein phosphatase 3, } \\
\text { catalytic subunit, alpha } \\
\text { isoform }\end{array}$ & Ppp3ca & $-1.00 \pm 0.23$ & $-2.14 \pm 0.09$ & $-1.82 \pm 0.21$ \\
\hline NM_134024 & Tubulin, gamma 1 & Tubg1 & $-1.04 \pm 0.18$ & $-1.34 \pm 0.15$ & $-1.76 \pm 0.13$ \\
\hline NM_153058 & $\begin{array}{l}\text { Microtubule-associated } \\
\text { protein, RP/EB family, } \\
\text { member 2 }\end{array}$ & Mapre2 & $-1.29 \pm 0.16$ & $-1.63 \pm 0.11$ & $-1.27 \pm 0.25$ \\
\hline NM_183178 & $\begin{array}{l}\text { Fibronectin type 3 and SPRY } \\
\text { domain-containing protein }\end{array}$ & Fsd1 & $-1.30 \pm 0.15$ & $-1.72 \pm 0.12$ & $-1.69 \pm 0.11$ \\
\hline NM_007595 & $\begin{array}{l}\text { Calcium/calmodulin- } \\
\text { dependent protein kinase II, } \\
\text { beta }\end{array}$ & Camk2b & $-1.31 \pm 0.13$ & $-2.47 \pm 0.06$ & $-1.71 \pm 0.11$ \\
\hline NM_133955 & $\begin{array}{l}\text { Ras homolog gene family, } \\
\text { member U }\end{array}$ & Rhou & $-1.53 \pm 0.14$ & $-1.50 \pm 0.12$ & $-1.22 \pm 0.20$ \\
\hline NM_177407 & $\begin{array}{l}\text { Calcium/calmodulin- } \\
\text { dependent protein kinase II } \\
\text { alpha }\end{array}$ & Camk2a & $-1.62 \pm 0.18$ & $-1.68 \pm 0.16$ & $-1.43 \pm 0.17$ \\
\hline
\end{tabular}


Supplementary table 4. Significantly expressed genes (with fold-change of at least \pm 1.5 in a minimum one out of three time-points and passed One-way ANOVA, $p<0.05)$ encoding for proteins involved in mitotic cell cycle upon $250 \mu \mathrm{M}$ Glu-mediated excitotoxicity in cultured primary cortical neurons. Data are expressed as mean \pm sem.

\begin{tabular}{|c|c|c|c|c|c|}
\hline & & & & $250 \mu \mathrm{M}$ Glu & \\
\hline Genbank & Gene & Symbol & $5 \mathbf{h}$ & $15 \mathrm{~h}$ & $24 h$ \\
\hline Mitotic cell cy & & & & & \\
\hline NM_011121 & Polo-like kinase 1 (Drosophila) & Plk1 & $2.08 \pm 0.32$ & $2.06 \pm 0.37$ & $1.62 \pm 0.30$ \\
\hline NM_007659 & Cyclin-dependent kinase 1 & Cdk1 & $2.06 \pm 0.42$ & $1.91 \pm 0.47$ & $1.50 \pm 0.39$ \\
\hline NM_011497 & Aurora kinase A & AurkA & $1.91 \pm 0.42$ & $1.98 \pm 0.50$ & $1.59 \pm 0.44$ \\
\hline NM_026410 & Cell division cycle associated 5 & Cdca5 & $1.88 \pm 0.45$ & $1.60 \pm 0.35$ & $1.35 \pm 0.33$ \\
\hline NM_175384 & Cell division cycle associated 2 & Cdca2 & $1.82 \pm 0.37$ & $1.70 \pm 0.35$ & $1.52 \pm 0.34$ \\
\hline NM_028390 & Anillin, actin binding protein & Anln & $1.80 \pm 0.40$ & $1.86 \pm 0.51$ & $1.67 \pm 0.41$ \\
\hline NM_026282 & $\begin{array}{l}\text { SPC24, NDC80 kinetochore } \\
\text { complex component, homolog (S. } \\
\text { cerevisiae) }\end{array}$ & Spc24 & $1.71 \pm 0.32$ & $1.67 \pm 0.55$ & $1.18 \pm 0.33$ \\
\hline NM_172301 & Cyclin B1 & Ccnb1 & $1.68 \pm 0.42$ & $2.09 \pm 0.54$ & $1.48 \pm 0.51$ \\
\hline NM_025565 & $\begin{array}{l}\text { SPC25, NDC80 kinetochore } \\
\text { complex component, homolog (S. } \\
\text { cerevisiae) }\end{array}$ & Spc25 & $1.66 \pm 0.41$ & $1.85 \pm 0.65$ & $1.47 \pm 0.63$ \\
\hline NM_023223 & $\begin{array}{l}\text { Cell division cycle } 20 \text { homolog } \\
\text { (S. cerevisiae) }\end{array}$ & Cdc20 & $1.61 \pm 0.41$ & $2.03 \pm 0.50$ & $1.32 \pm 0.36$ \\
\hline NM_026560 & Cell division cycle associated 8 & Cdca8 & $1.61 \pm 0.57$ & $1.43 \pm 0.48$ & $1.06 \pm 0.36$ \\
\hline NM_013538 & Cell division cycle associated 3 & Cdca3 & $1.57 \pm 0.39$ & $2.03 \pm 0.48$ & $1.43 \pm 0.39$ \\
\hline NM_009689 & $\begin{array}{l}\text { Baculoviral IAP repeat- } \\
\text { containing } 5\end{array}$ & Birc5 & $1.54 \pm 0.36$ & $1.88 \pm 0.50$ & $1.34 \pm 0.30$ \\
\hline NM_017407 & Sperm associated antigen 5 & Spag5 & $1.52 \pm 0.38$ & $1.85 \pm 0.46$ & $1.55 \pm 0.48$ \\
\hline NM_007893 & E4F transcription factor 1 & E4f1 & $1.52 \pm 0.40$ & $1.09 \pm 0.33$ & $1.03 \pm 0.35$ \\
\hline NM_008682 & $\begin{array}{l}\text { Neural precursor cell expressed, } \\
\text { developmentally down-regulated } \\
\text { gene } 1\end{array}$ & Nedd 1 & $1.40 \pm 0.29$ & $1.84 \pm 0.42$ & $1.65 \pm 0.42$ \\
\hline NM_009831 & Cyclin G1 & Ccng & $1.36 \pm 0.31$ & $1.52 \pm 0.39$ & $1.31 \pm 0.29$ \\
\hline NM_010578 & $\begin{array}{l}\text { Integrin beta } 1 \text { (fibronectin } \\
\text { receptor beta) }\end{array}$ & Itgb1 & $1.34 \pm 0.22$ & $1.64 \pm 0.28$ & $1.46 \pm 0.32$ \\
\hline NM_013917 & $\begin{array}{l}\text { Pituitary tumor-transforming } \\
\text { gene } 1\end{array}$ & Pttg1 & $1.29 \pm 0.44$ & $1.71 \pm 0.72$ & $1.27 \pm 0.45$ \\
\hline$N M_{-} 144818$ & $\begin{array}{l}\text { Non-SMC condensin I complex, } \\
\text { subunit H }\end{array}$ & Ncaph & $1.24 \pm 0.49$ & $1.71 \pm 0.55$ & $1.53 \pm 0.49$ \\
\hline NM_033270 & E2F transcription factor 6 & E2f6 & $1.22 \pm 0.24$ & $1.68 \pm 0.42$ & $1.53 \pm 0.39$ \\
\hline NM_023317 & $\begin{array}{l}\text { Nuclear distribution gene } \mathrm{E} \\
\text { homolog } 1 \text { (A nidulans) }\end{array}$ & Nde1 & $1.13 \pm 0.30$ & $1.77 \pm 0.43$ & $1.35 \pm 0.35$ \\
\hline NM_022889 & $\begin{array}{l}\text { Pescadillo homolog 1, containing } \\
\text { BRCT domain (zebrafish) }\end{array}$ & Pes1 & $1.12 \pm 0.22$ & $1.49 \pm 0.33$ & $1.31 \pm 0.28$ \\
\hline NM_007471 & $\begin{array}{l}\text { Amyloid beta (A4) precursor } \\
\text { protein }\end{array}$ & App & $1.06 \pm 0.20$ & $-1.64 \pm 0.12$ & $-1.56 \pm 0.14$ \\
\hline NM_008913 & $\begin{array}{l}\text { Protein phosphatase } 3 \text {, catalytic } \\
\text { subunit, alpha isoform }\end{array}$ & Рpp3ca & $1.03 \pm 0.20$ & $-1.71 \pm 0.11$ & $-1.48 \pm 0.12$ \\
\hline
\end{tabular}




\begin{tabular}{|l|l|c|c|c|c|}
\hline NM_007595 & $\begin{array}{l}\text { Calcium/calmodulin-dependent } \\
\text { protein kinase II, beta }\end{array}$ & Camk2b & $-1.18 \pm 0.13$ & $-2.33 \pm 0.09$ & $-1.74 \pm 0.11$ \\
\hline NM_198429 & $\begin{array}{l}\text { Nuclear factor of activated T- } \\
\text { cells, cytoplasmic, calcineurin- } \\
\text { dependent 1 }\end{array}$ & Nfatc1 & $-1.29 \pm 0.23$ & $1.50 \pm 0.41$ & $1.61 \pm 0.45$ \\
\hline NM_153058 & $\begin{array}{l}\text { Microtubule-associated protein, } \\
\text { RP/EB family, member 2 }\end{array}$ & Mapre2 & $-1.29 \pm 0.15$ & $-1.51 \pm 0.14$ & $-1.27 \pm 0.17$ \\
\hline NM_133955 & $\begin{array}{l}\text { Ras homolog gene family, } \\
\text { member U }\end{array}$ & Rhou & $-1.30 \pm 0.16$ & $-1.62 \pm 0.15$ & $-1.31 \pm 0.14$ \\
\hline NM_152804 & Polo-like kinase 2 (Drosophila) & Plk2 & $-1.37 \pm 0.18$ & $-1.82 \pm 0.12$ & $-1.46 \pm 0.20$ \\
\hline NM_031166 & Inhibitor of DNA binding 4 & Id4 & $-1.41 \pm 0.21$ & $1.93 \pm 0.56$ & $2.11 \pm 0.76$ \\
\hline NM_177407 & $\begin{array}{l}\text { Calcium/calmodulin-dependent } \\
\text { protein kinase II alpha }\end{array}$ & Camk2a & $-1.42 \pm 0.19$ & $-1.67 \pm 0.21$ & $-1.44 \pm 0.24$ \\
\hline
\end{tabular}




\section{Highlights}

- Gene activation is profiled in neurons treated with ionotropic L-glutamate agonists

- Common profiles in excitotoxicity show pivotal roles for NMDA and kainate receptors

- Aberrant calcium ion homeostasis occurs with organelle stress and death signalling

- Functional annotation revealed oxidative stress and major cell cycle re-activation

- The latter downstream targets fulfil the "two-hit" hypothesis of neurodegeneration 


\section{University Library}

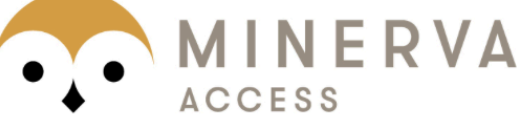

A gateway to Melbourne's research publications

Minerva Access is the Institutional Repository of The University of Melbourne

Author/s:

Chen, MJ;Ng, JMJ;Peng, ZF;Manikandan, J;Yap, YW;Llanos, RM;Beart, PM;Cheung, NS

Title:

Gene profiling identifies commonalities in neuronal pathways in excitotoxicity: Evidence favouring cell cycle re-activation in concert with oxidative stress

Date:

2013-04-01

\section{Citation:}

Chen, M. J., Ng, J. M. J., Peng, Z. F., Manikandan, J., Yap, Y. W., Llanos, R. M., Beart, P. M. \& Cheung, N. S. (2013). Gene profiling identifies commonalities in neuronal pathways in excitotoxicity: Evidence favouring cell cycle re-activation in concert with oxidative stress. NEUROCHEMISTRY INTERNATIONAL, 62 (5), pp.719-730. https://doi.org/10.1016/ j.neuint.2012.12.015.

Publication Status:

Accepted manuscript

Persistent Link:

http://hdl.handle.net/11343/41848 